DiRECTEURS DE LA PUBLICATION / PUBLICATION DIRECTORS:

Bruno David, Président du Muséum national d'Histoire naturelle

Étienne Ghys, Secrétaire perpétuel de l'Académie des sciences

RÉDACTEURS EN CHEF / EDITORS-IN-CHIEF: Michel Laurin (CNRS), Philippe Taquet (Académie des sciences)

AssistANTE dE RÉDACTION / AssISTANT EDITOR: Adeline Lopes (Académie des sciences ; cr-palevol@academie-sciences.fr)

MISE EN PAGE / PAGE LAYOUT: Emmanuel Côtez (Muséum national d'Histoire naturelle)

RÉDACTEURS ASSOCIÉS / ASSOCIATE EDITORS ( ${ }^{*}$, took charge of the editorial process of the article/a pris en charge le suivi éditorial de l'article):

Micropaléontologie/Micropalaeontology

Maria Rose Petrizzo (Università di Milano, Milano)

Paléobotanique/Palaeobotany

Cyrille Prestianni (Royal Belgian Institute of Natural Sciences, Brussels)

Métazoaires/Metazoa

Annalisa Ferretti (Università di Modena e Reggio Emilia, Modena)

Paléoichthyologie/Palaeoichthyology

Philippe Janvier (Muséum national d'Histoire naturelle, Académie des sciences, Paris)

Amniotes du Mésozoïque/Mesozoic amniotes

Hans-Dieter Sues (Smithsonian National Museum of Natural History, Washington)

Tortues/Turtles

Juliana Sterli (CONICET, Museo Paleontológico Egidio Feruglio, Trelew)

Lépidosauromorphes/Lepidosauromorphs

Hussam Zaher (Universidade de São Paulo)

Oiseaux/Birds

Éric Buffetaut (CNRS, École Normale Supérieure, Paris)

Paléomammalogie (petits mammifères)/Palaeomammalogy (small mammals)

Robert Asher (Cambridge University, Cambridge)

Paléomammalogie (mammifères de moyenne et grande taille)/Palaeomammalogy (large and mid-sized mammals)

Lorenzo Rook (Università degli Studi di Firenze, Firenze)

Paléoanthropologie/Palaeoanthropology

Roberto Macchiarelli (Université de Poitiers, Poitiers)

Archéologie préhistorique/Prehistoric archaeology

Marcel Otte* (Université de Liège, Liège)

COUVERTURE / COVER:

Made from the Figures of the article.

Comptes Rendus Palevol est indexé dans / Comptes Rendus Palevol is indexed by:

- Cambridge Scientific Abstracts

- Current Contents ${ }^{\circ}$ Physical

- Chemical, and Earth Sciences ${ }^{\circledR}$

- ISI Alerting Services ${ }^{\circledR}$

- Geoabstracts, Geobase, Georef, Inspec, Pascal

- Science Citation Index ${ }^{\circledR}$, Science Citation Index Expanded ${ }^{\circledR}$

- Scopus ${ }^{\circledR}$

Les articles ainsi que les nouveautés nomenclaturales publiés dans Comptes Rendus Palevol sont référencés par / Articles and nomenclatural novelties published in Comptes Rendus Palevol are registered on:

- ZooBank ${ }^{\circledR}$ (http://zoobank.org)

Comptes Rendus Palevol est une revue en flux continu publiée par les Publications scientifiques du Muséum, Paris et l'Académie des sciences, Paris Comptes Rendus Palevol is a fast track journal published by the Museum Science Press, Paris and the Académie des sciences, Paris

Les Publications scientifiques du Muséum publient aussi / The Museum Science Press also publish:

Adansonia, Geodiversitas, Zoosystema, Anthropozoologica, European Journal of Taxonomy, Naturae, Cryptogamie sous-sections Algologie, Bryologie, Mycologie.

L'Académie des sciences publie aussi / The Académie des sciences also publishes:

Comptes Rendus Mathématique, Comptes Rendus Physique, Comptes Rendus Mécanique, Comptes Rendus Chimie, Comptes Rendus Géoscience, Comptes Rendus Biologies.

Diffusion - Publications scientifiques Muséum national d'Histoire naturelle

CP $41-57$ rue Cuvier F-75231 Paris cedex 05 (France)

Tél. : 33 (0)1 40794805 / Fax: 33 (0)1 40793840

diff.pub@mnhn.fr / http://sciencepress.mnhn.fr

Académie des sciences, Institut de France, 23 quai de Conti, 75006 Paris.

(C) Publications scientifiques du Muséum national d'Histoire naturelle / (C) Académie des sciences, Paris, 2020

ISSN (imprimé / print): 1631-0683/ ISSN (électronique / electronic): 1777-571X 


\section{Fluvial dynamics and palaeolithic settlement: new data from the Côa Valley (Portugal)}

\section{Thierry AUBRY André Tomás SANTOS Luís LUís}

Côa Parque, Fundação para a Salvaguarda e Valorização do Vale do Côa,

Rua do Museu, 5150-610 Vila Nova de Foz Côa (Portugal) and UNIARQ - Centro de Arqueologia Universidade de Lisboa, Faculdade de Letras, Alameda da Universidade, 1600-214 Lisboa (Portugal) thierryaubry@arte-coa.pt andresantos@arte-coa.pt

luisluis@arte-coa.pt

António Fernando BARBOSA Marcelo SILVESTRE

Côa Parque, Fundação para a Salvaguarda e Valorização do Vale do Côa, Rua do Museu, 5150-610 Vila Nova de Foz Côa (Portugal) fernandobarbosa@arte-coa.pt marcelosilvestre@arte-coa.pt

Submitted on 21 September 2019 | accepted on 29 November 2019 | published on 2 November 2020

urn:Isid:zoobank.org:pub:D5E1C4B2-0893-4916-9F8B-F2AFF7BDA354

Aubry T., Santos A. T., Luís L., Barbosa A. F. \& Silvestre M. 2020. - Fluvial dynamics and palaeolithic settlement: new data from the Côa Valley (Portugal), in Rodríguez-Álvarez X. P., Otte M., Lombera-Hermida A. de \& Fábregas-Valcarce R. (eds), Palaeolithic of Northwest Iberia and beyond: multidisciplinary approaches to the analysis of Late Quaternary hunter-gatherer societies. Comptes Rendus Palevol 19 (7): 117-135. https://doi.org/10.5852/cr-palevol2020v19a7

KEY WORDS

Côa Valley,

palaeolithic rock art, alluvial system,

dating,

conservation.

MOTS CLÉS

Vallée du Côa,

gravures paléolithiques, système alluvial, datation,

conservation.

\section{ABSTRACT}

The geomorphological context of the Côa Valley open-air Palaeolithic rock art offers a unique opportunity to analyse its stratigraphic relationship with preserved Quaternary deposits and to reconstruct those that may have since disappeared. Litho-stratigraphic units, discontinuities and their architecture are interpreted in the context of the valley's evolution and its environment. The spatial distribution of rock art panels, chronological attribution of the rock art and their geomorphological context can help us to reconstruct the topography of the valley at the time of its production and to identify where rock art panels could be buried, as well as to establish their chronology.

\section{RÉSUMÉ}

Dynamiques fluviales et occupation humaine paléolithique : nouvelles données de la vallée du Côa (Portugal). Le contexte géomorphologique des gravures paléolithiques de plein air de la vallée du Côa offre une possibilité unique d'analyser leur relation stratigraphique avec des dépôts quaternaires conservés et de reconstituer ceux qui ont disparu depuis leur réalisation. Les ensembles litho-stratigraphiques, les discontinuités et leur organisation sont interprétés dans le cadre de l'évolution de la vallée et de son environnement. A partir de la localisation, de l'attribution chronologique et du contexte géomorphologique actuel des gravures, nous reconstituons la vallée au moment de leur réalisation et où peuvent être enfouis des panneaux gravés et de quelles chronologies. 


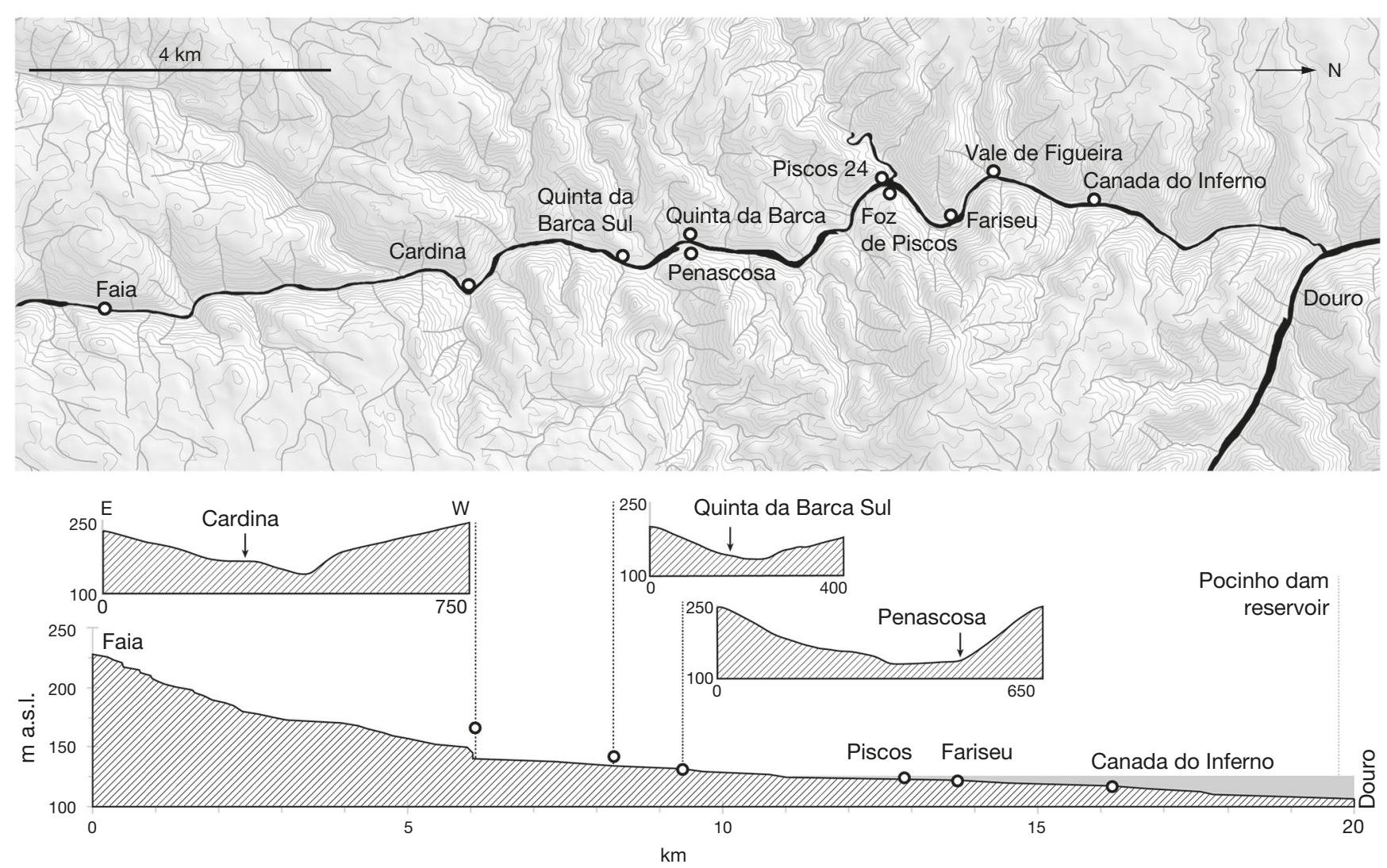

FIG. 1. - Longitudinal profile of the last $20 \mathrm{~km}$ of the Côa River and sites mentioned in the text (25 meter contour lines).

\section{INTRODUCTION}

The discovery and stylistic dating of the pecked horse of Mazouco (North of Portugal) from the Upper Palaeolithic was the first step to the realization that open-air rock art of this period could have survived until the present (Jorge et al. 1981). It paved the way for new discoveries in Spain, notably in the nearby site of Siega Verde (Alcolea González \& Balbín Behrmann 2006; Balbin Behrmann et al. 1991), in Domingo García (Ripoll López \& Municio González 1992, 1999) and in Piedras Blancas (Martínez García 1986-1987), as well as Fornols-Haut, in the French Pyrenees (Bahn 1985; Sacchi et al. 1988). The discussions that followed the public announcement of the Palaeolithic rock art of the lower Côa catchment (Rebanda 1995) led to the establishment of a research program in the region (e.g. Aubry 2009d; Baptista 2009; Santos 2017; Zilhão 1997), as well as to the discovery of several other Portuguese sites (Santos et al. 2015). Also in Spain, but close to the Portuguese border, other sites were later discovered (Collado 2006; Vázquez \& Reis 2019).

More than 530 rocks with Pleistocene rock art are known today in the Côa Valley (Reis 2014). These rocks are irregularly distributed over 48 sites, 25 of them located along the river margins of the last eight $\mathrm{km}$ of the Côa Valley, two of them in the higher basin of the river, and the last 21 spread along several tributaries of the Douro river, immediately upstream and downstream the confluence of the Côa (e.g. Santos et al.
2019). The geological context of the region is essentially made of granites and Precambrian and Palaeozoic metamorphic rocks. The panels used for engraving represent joint/fractures resulting from the tectonic stress caused by a NNE-SSW left strike-slip fault system that crosses the region (Aubry et al. 2012, 2017). The most depicted themes are aurochs, horses, ibexes and red deer, although anthropomorphic figures, chamois and fishes are also present in fewer, but not negligible, numbers (Santos 2017). Bison, carnivores and birds are marginal themes.

The Côa Valley rock art is essentially engraved through the use of different techniques (Santos 2017). Incision is the most common, used under different forms: simple incision, multiple incisions and repeated incision. Pecking is identified under two variants distinguished by the degree of density of the resulting negatives. Abrasion is commonly identified in association with pecking, but it can also appear on its own. Scraping is the least used of the engraving techniques. Animals can have their bodies partially or fully filled with incisions or pecked areas. Painting is only known in the two panels of Rock 7 at Faia, protected by a shelter, where red pigment was used in association with pecking and abrasion to depict five aurochs' heads and one horse's head (e.g. Baptista 2009).

Four phases of Pleistocene rock art were identified in the Côa Valley (Santos 2017). This phasing is essentially based on the study of the stratigraphy between motifs that a Hierarchical Cluster Analysis, made on top of a Multiple Correspondence analysis, suggested to pertain to different clusters based on 


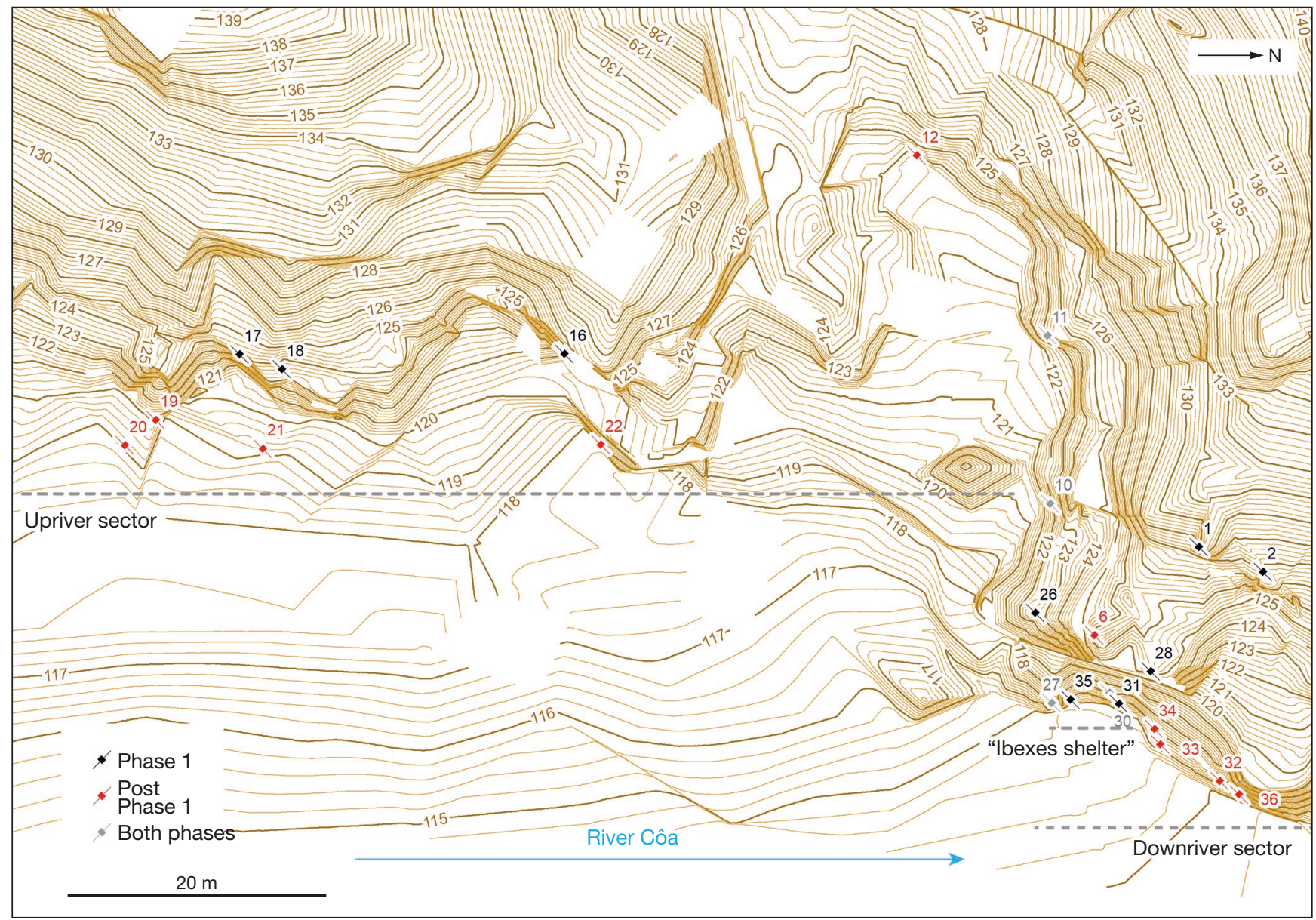

FIG. 2. - Spatial distribution of the rock art assigned to the phase 1 and post-phase 1 in Canada do Inferno.

their technological and morphological attributes. The first phase is dated from a period between the Gravettian and the Middle Solutrean, as shown by the geoarchaeological analysis of the relation between the sedimentary cycle identified in the site of Fariseu and the rock art found in panel 1 of the site, providing a terminus ante quem (Aubry et al. 2014 and see below). The second and third phases are difficult to date, but the study of the topographic location of the rocks with motifs from phase 1 and rocks with phase 2 motifs in Canada do Inferno's upriver sector (Figs 1-3), coupled with the data provided by the excavations at Fariseu, suggest that the former were probably engraved over a soil that was eroded by fluvial action at some point before $c .22000 \mathrm{cal} \mathrm{BP}$. As such, this date is also the terminus post quem for phase 2. Superimpositions between motifs of phase 2, 3 and 4 prove that this sequence is correct, but only for phase 4 do we have evidence that enable us to date it absolutely. This evidence comes from the portable art of Fariseu (94 pieces), recovered in the GFU 4, attributed to the Azilian and dated of 12000-11000 cal BP (Santos et al. 2018). Phases 2 and 3 are surely dated between the other ones. Stylistic parallels for these phases are found, especially in the Franco-Cantabrian zone, in sites invariably dated from the Late Solutrean-Early Magdalenian (phase 2) and from the Middle Magdalenian-Upper Magdalenian (phase 3) (Santos 2017).
This sequence of graphic production is compatible with the chrono-stratigraphic frame of the human occupation of the Côa Valley, which is based on the categorization and technology of stone tools (Aubry 2001, 2002, 2009d; Aubry \& García Díez 2000; Aubry et al. 2002; Zilhão 1995, 1997), as well as on absolute dating by thermoluminescence (Mercier et al. 2001; Valladas et al. 2001) and luminescence (Aubry et al. 2020).

Upper Palaeolithic occupation of the region starts at the end of the Aurignacian (Aubry et al. 2019) and continues during several phases of the Gravettian, Solutrean, Magdalenian and Azilian (Aubry 2009a). The discovery and excavation of the site of Fariseu in 1999 enabled the study of the stratigraphic relations between the 89 engraved motifs, mainly pecked and abraded, identified on its Rock 1 and the evidence of several Palaeolithic occupations that were identified alongside. Some of these occupations were dated on the basis of typo-technological arguments and absolute dating (TL, OSL and C14), confirming the stylistic dating of the Upper Palaeolithic rock art (Aubry et al. 2006; Mercier et al. 2006) and assuring us that the panel was a composition made in a short time, before 22000 cal BP (Aubry et al. 2014). Differential conservation of the engraving, due to natural causes (Aubry et al. 2012, 2017), and the theoretical possibility of a non-synchronic relation between the archaeological context 
TABLE 1. - Côa Valley Quaternary deposits correlation: a, C14 cal BP ages, Calibration used CalPal with the Calcurve CalPal_2007_HULU (www.calpal-online. de). All the errors are 1-sigma; b, TL ages; c, OSL ages; 1, Valladas et al. 2001; 2, Aubry et al. 2020; 3, Aubry et al. 2017; 4, Mercier et al. 2006; 5, Aubry 2009d; 6, Zilhão 1997.

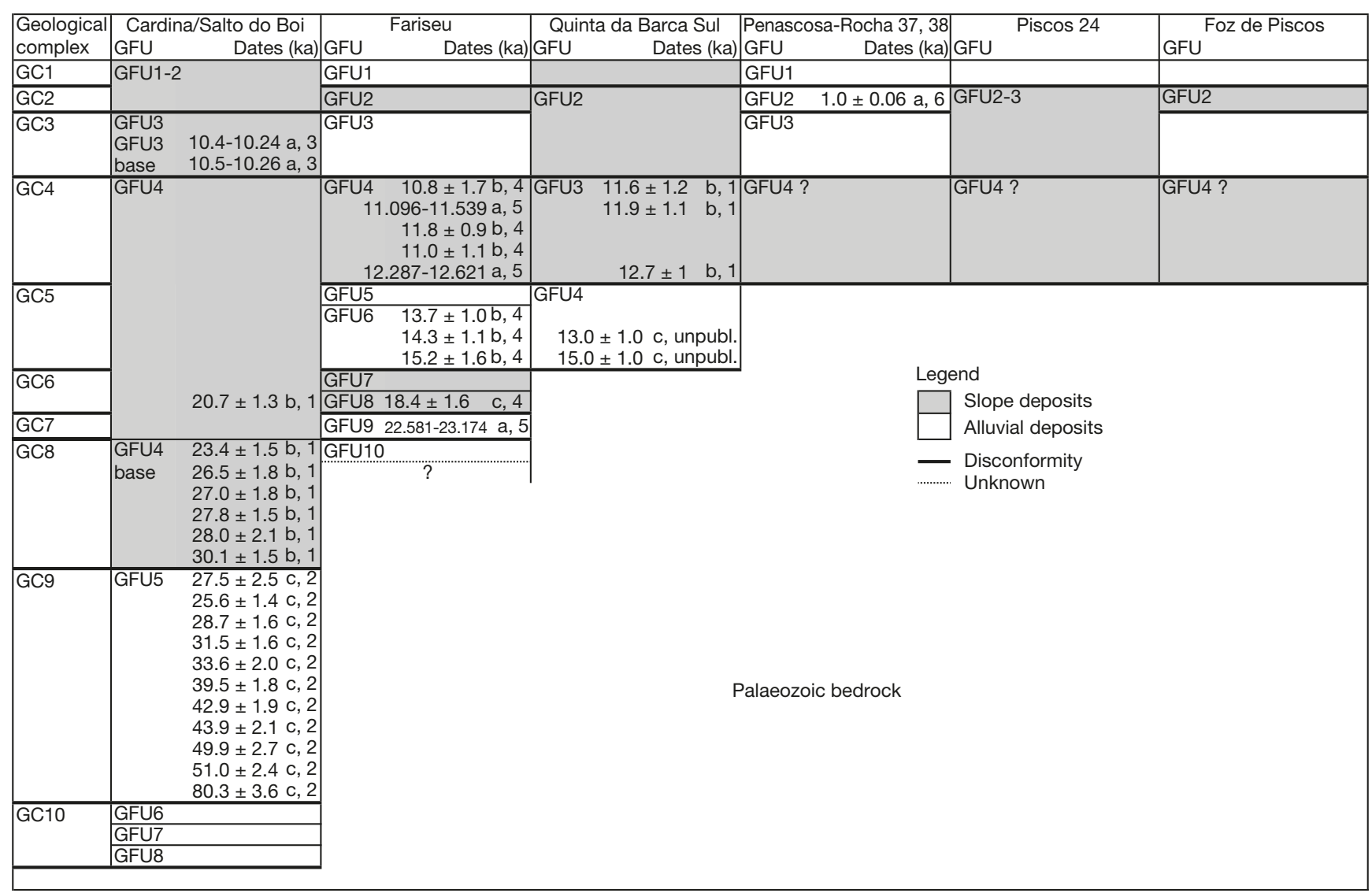

of the valley and rock art production (Zilhão 2003) must be considered before any interpretation of the spatial distribution of rock art and archaeological sites. This kind of analysis is likely to fail if one chooses to ignore the evolution of the environment after the rock art production and its effects on the conservation of the rock art.

Based on the fact that the present-day distribution of the rock art along the last $20 \mathrm{~km}$ of the valley follows metamorphic rocks, almost entirely avoiding granites, and taking into account conservation biases, a first hypothesis for the presentday distribution of the rock art was proposed (Aubry et al. 2002). The hypothesis that the current distribution of rock art is highly conditioned by natural causes was further explored in a pair of studies that involved analysis of satellite images, aerial photographs, and several field and lab studies, namely GIS (Aubry et al. 2012, 2017). These studies showed the importance of the orientation of the regional tectonic fracturing that produced the vertical joint/fractures used as support for the rock art, determining solar exposition and humidity as crucial factors for the subsequent colonization of the surfaces by lichens and bryophytes and ensuing weathering.

At the same time these studies were being undertaken, the observations and analyses of the quaternary sedimentary units of the excavated archaeological sites and their dating provided evidence for a close relationship between the processes and sedimentary environments inferred by local observations and the Late Glacial climatic oscillations, defined by the study of the marine record. Data suggests that the architecture of the alluvial plain filling was regularly modified over the last 30000 years and that the engraved rocks located around the alluvial plain should have been repeatedly covered by alluvial and colluvial deposits, which were subsequently eroded by fluvial action (Aubry 2009b; Aubry et al. 2010, 2014). It was this kind of observation that led us to propose that the different locations of motifs of different phases, such as in Canada do Inferno (Figs 2; 3), Vale de Figueira, Quinta da Barca and Penascosa, could be explained by the occurrence of erosional episodes between different phases (Santos 2017).

\section{METHODS}

This study follows the same approach and framework presented in previous papers (Aubry 2009c, Aubry et al. 2012, 2014). It is based on the data provided by the geoarchaeological analysis (Angelucci 2003; Brown 1997) of the lithostratigraphic sequences discovered during the archaeological excavations that have been taken place along the last $20 \mathrm{~km}$ of the Côa river basin for the past two decades. Macroscopic description of the lithostratigraphic units of the alluvial plain uses the 

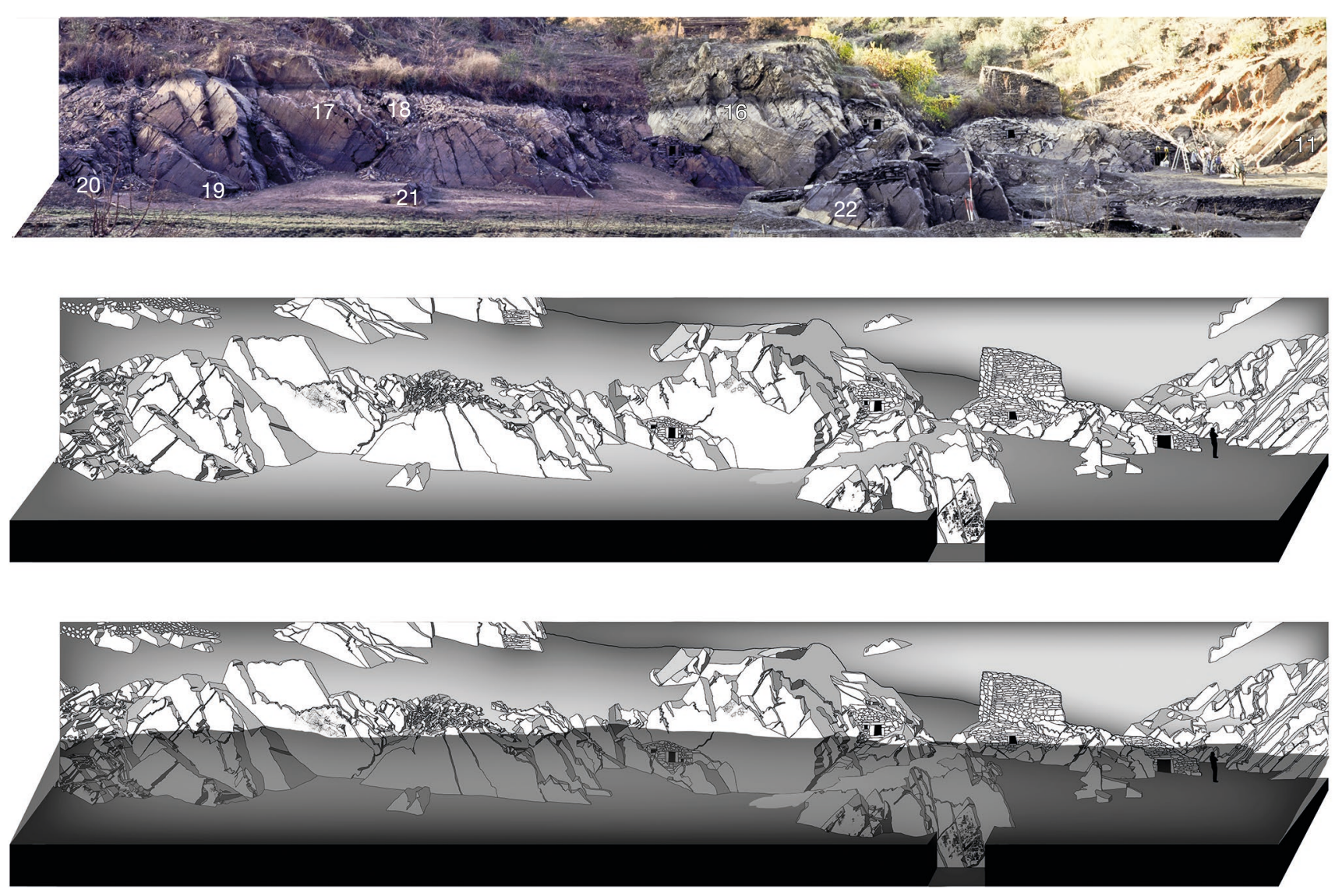

FIG. 3. - Hypothetical reconstruction of the phase 1 rock art soil topography during its production, from photographs taken during the lowering of Pocinho Dam in 1995. The numbers correspond to the different engraved panels. Shaded area in the bottom image corresponds to the hypothetical top soil during phase 1.

categories proposed by Miall (1983), considering new geological data (Aubry et al. 2020), and the micromorphological study of the blocs of sediment of Fariseu (Sellami 2009) and of Cardina/Salto do Boi (Bergadà 2009).

We have taken into account the archaeological content of the lithostratigraphic units of each site (Aubry 2009a), correlating them with the associated absolute TL (Gif-surYvette), OSL (Gif-sur-Ivette, Risø) and C14 (Beta Analytic, Groningen, Geochron, Uppsala) ages (Aubry 2009c; Mercier et al. 2006; Valladas et al. 2001) (Table 1).

Because the main goal of our study is to study the relationship between the deposits of the bottom of the valley and the engraved panels, our analysis will focus on the alluvial plain. This is where the majority of phase 1 panels can be found (e.g. Zilhão 1997; Santos 2017), as well as some later panels that are critical to our present study (Santos 2017).

In our previous work on Rock 1 at Fariseu (Aubry et al. 2014), we have analysed the stratigraphic relationship between its artistic composition and adjacent deposits, both preserved and eroded after the engraving of the rock. In this paper we will extend the analysis to larger areas of the valley.

To do this, we will analyse spatially the rock art motifs located on the valley bottom, correlating their phase of production with altimetric position, as well as inferring the periods those rocks were exposed or covered, and determining their past and present sedimentary contexts. The results that we have obtained in the latest excavations of Cardina/Salto do Boi (Aubry et al. 2015, 2018, 2019, 2020), located three $\mathrm{km}$ upstream from the rock art sites of Penascosa and Quinta da Barca, are of paramount significance to inform us about those past sedimentary contexts, namely the identification of alluvial deposits with a Middle and Early Upper Palaeolithic lithic industries, $20 \mathrm{~m}$ above the present-day Côa riverbed. The importance of this finding led us to obtain luminescence dates to this deposit. An alluvial deposit of Quinta da Barca Sul, located between Cardina/Salto do Boi and the sites of Penascosa and Quinta da Barca, was also dated. Excavations at Penascosa (2018) and Foz de Piscos (2019) contributed to increase our understanding of the fluvial system dynamics and to test some previous hypotheses regarding the sedimentary cycle of the river valley.

\section{RESULTS}

Cardina/Salto do Boi: From Granite

TO METAMORPHIC ROCKS

Cardina/Salto do Boi was the first site of the Côa Valley where an Upper Palaeolithic human occupation was identified. The site is located on the left bank of the river Côa, $500 \mathrm{~m}$ downriver from the granite rocks that characterize the large majority of the first $100 \mathrm{~km}$ of its course (Fig. 1). The 


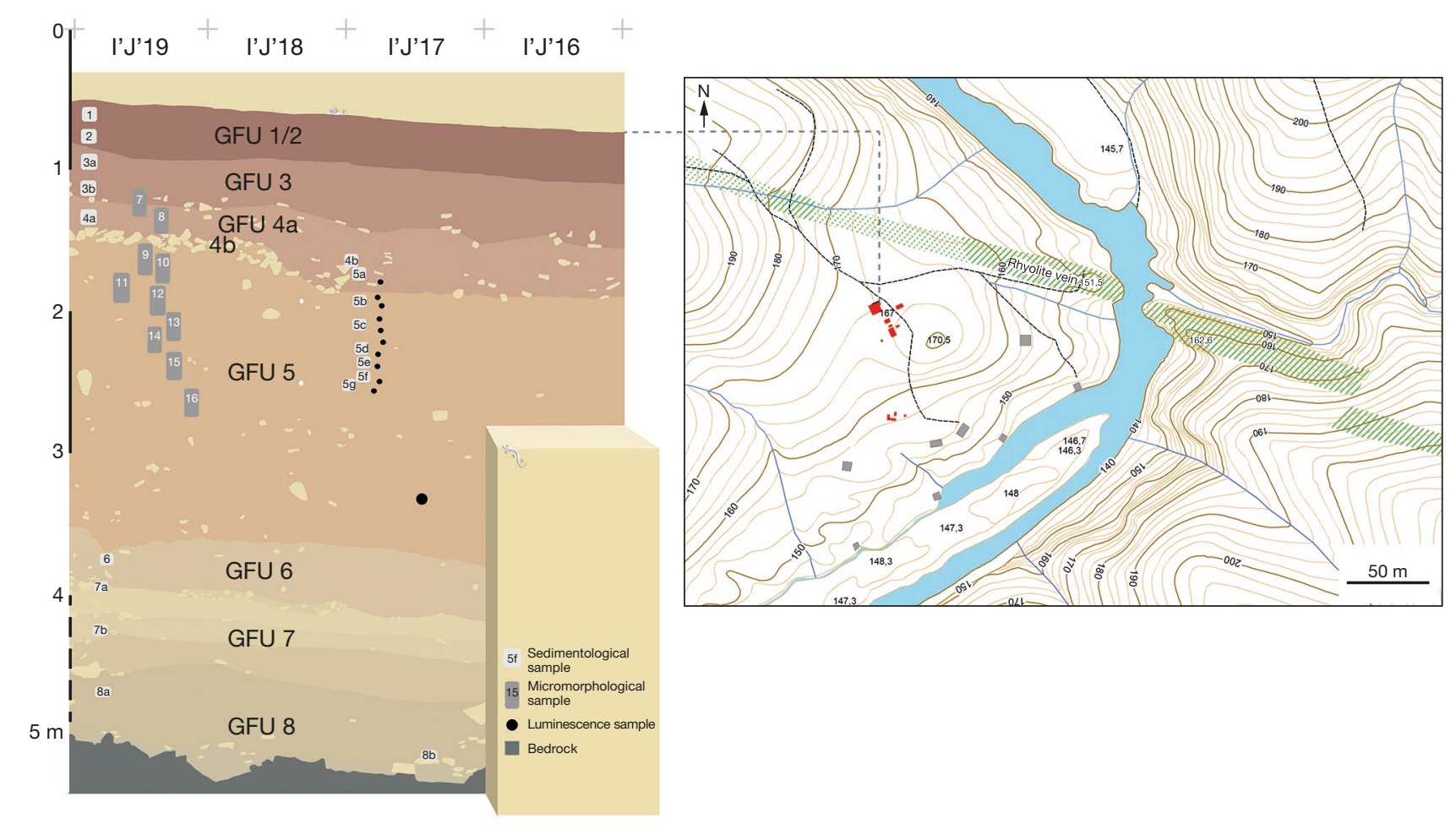

FIG. 4. - Topographic map of the Cardina/Salto do Boi site, with the excavated area at the end of the 2018 field season and reference cross-section.

archaeological remains are found in a topographic platform located $167.5 \mathrm{~m}$ above sea level (m a.s.l.) and $20 \mathrm{~m}$ above the present-day Côa riverbed (m a.r.b) (Fig. 4). The crosssection exposed in areas excavated between 1997 and 2018 revealed the existence of a $5 \mathrm{~m}$-thick stratigraphic succession on a phyllite bedrock. Eight field units (GFU 1 to 8) were distinguished during field work and grouped into two main geoarchaeological complexes (Fig. 4; Table 1). Sedimentary clay mineralogy (Luca Dimuccio) has shown that the first 4 $\mathrm{m}$ of deposits (layers 8 to 5) consist of tabular fine-grained bodies with low gravel content and a very poorly sorted sand mud fraction, enriched with both silt and sand, with secondary amounts of clay, deposited in a low energy environment of an ancient course of the river Côa. The sedimentary infill of GFU 8 to 5 depositional environments represents low-energy diffuse waterflow conditions that occurred relatively close to the ancient channel margin, interrupted by environmental stabilization phases without clear erosion.

Luminescence dates obtained over quartz grains and feldspar, as well as the technology and categorization of the lithic remains, indicate that this alluvial environment characterized all the Middle Palaeolithic (from earlier than the $80 \mathrm{ka}$, based on the luminescence date of the base of layer 5), the Late Aurignacian, Gravettian and Late Gravettian occupation (Aubry et al. 2019).

The uppermost metre of the sequence (GFU 4 to 1 ) is characterized by slope deposits resulting from gravity-driven processes (Bergadà 2009), containing lithic remains of several occupations of the site, from the Middle Solutrean to the present day (Aubry et al. 2019).
Cardina/Salto do Boi is a reference site for our understanding of human occupation of the region, from the Middle Palaeolithic onward, also providing precious data on the nature of the preserved deposits and the fluvial dynamics of the river Côa during the Middle Palaeolithic to Early Upper Palaeolithic. It reveals a dramatic change of the fluvial system after the granites, which dominate the previous sector of its basin. This change was most probably accelerated by the breaking of a rhyolite vein that is affected by several faults and forms a roughly right angle with the riverbed (Fig. 4).

This post 26000-28 000 cal BP change of the basal level of the course of the river after its entry in the metamorphic rocks must have had a huge impact on the hydrologic dynamics of the last 15 kilometres of its course, most notably on the level of the sedimentary infilling of the valley, and the evolution of the fluvial system.

\section{Quinta da Barca Sul: Confirmation of a GENERALISED} ALLUVIAL ACCRETION IN THE DOURO BASIN

This site is located two $\mathrm{km}$ downstream from Cardina/Salto do Boi, on the same riverbank, $142 \mathrm{~m}$ a.s.l. and $10 \mathrm{~m}$ a.r.b (Fig. 1). The bedrock of the topographic platform was reached during excavation and it was interpreted as a rock terrace (Zilhão 1997). The excavation revealed a sequence of slope deposits (GFU 1-3; Table 1). The oldest (GFU 3) could be correlated with a general phase of destruction and destabilization by gravity-driven processes of the rock slope of the valley during the Dryas III (Aubry et al. 2010), based on the Azilian lithic remains it contained and TL ages (Valladas et al. 2001). A fine-grained sand deposit was identified bellow these 


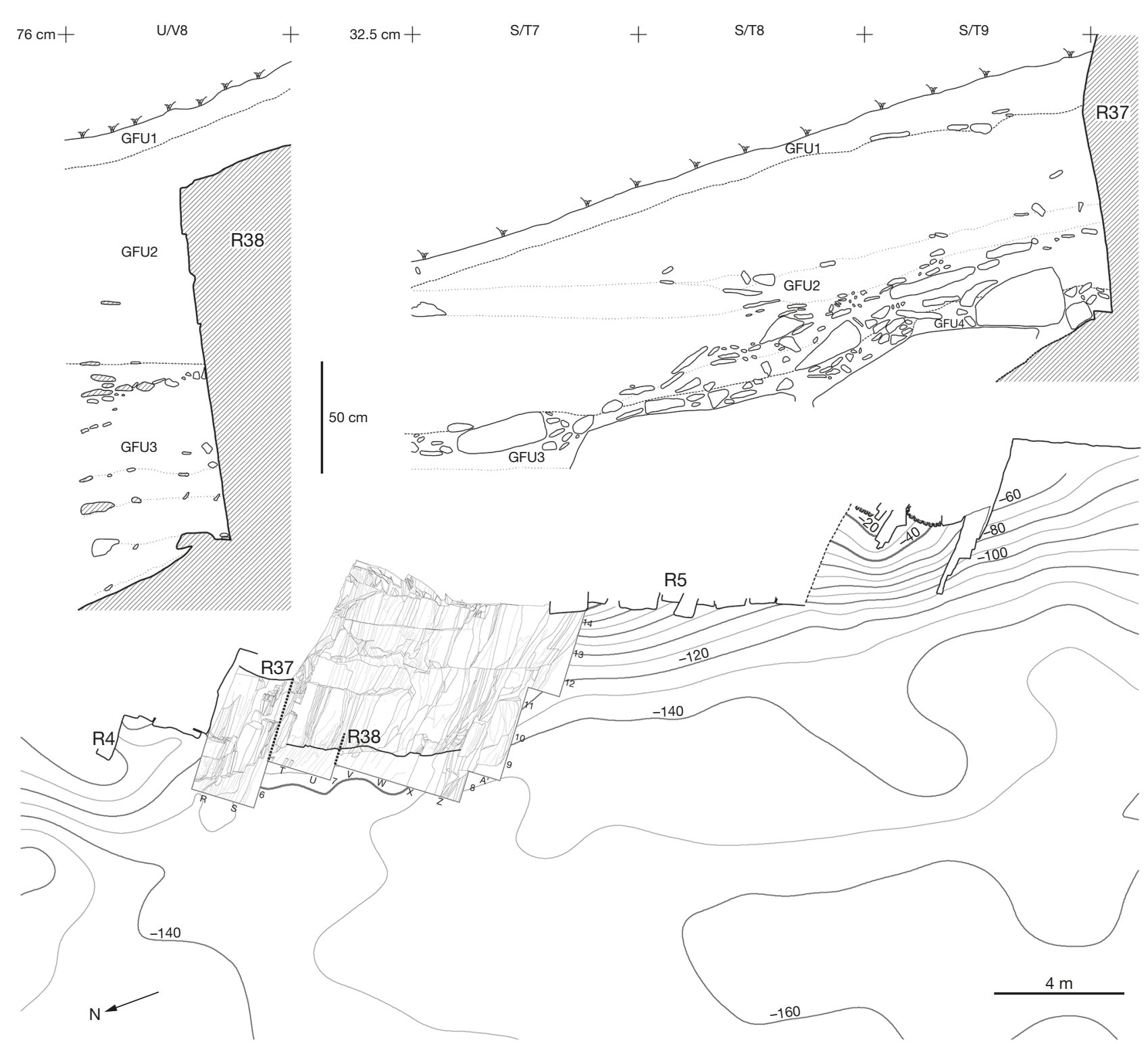

FIG. 5. - Area excavated during 2018 and 2019 in Penascosa site and cross-sections in front of the panel 37 and 38.

colluviums. The lithic remains of GFU 4 , located $\sim 8 \mathrm{~m}$ a.r.b, although generally dated from the Palaeolithic, do not permit us to determine a more precise date. Two luminescence dates obtained in 2018 in the Risø laboratory, over feldspar grains from a sample collected at the bottom of the sedimentary filling, place the human occupation between 13 and $15 \mathrm{ka}$ (Table 1). This phase of alluvial accretion is statistically equivalent to other luminescence ages obtained on alluvial fine sand and silt deposits of the region, namely in Fariseu, Vale Meão and Cortes da Veiga. During the excavation of the area facing Fariseu's Rock 1, located on the left bank of the Côa, a stratigraphic alluvial unit was identified (GFU 6) and dated through OSL of $15200 \pm 100$, and through TL over quartzite pebbles of $13700 \pm 1000$ and $14300 \pm 1100$ (Mercier et al. 2006; Table 1). Vale Meão and Cortes da Veiga are located in a meander of the river Douro, near Pocinho, a few kilometres downstream from the confluence of the Côa with the Douro.
At both these sites, several similar OSL dates were obtained on alluvial deposits of fine-grained sands with carbonated concretions (T1) (Cunha et al. 2019; Rockwell et al. 2009).

PENASCOSA: AdAPTATION OF THE ALLUVIAL SYSTEM TO THE METAMORPHIC ROCKS

Both the data obtained at Cardina/Salto do Boi and the hypothesis that at Penascosa rock art from phase 1 was higher in the slope than later phases due to the existence of an erosional episode, as it is more clear in Canada do Inferno's upriver sector and Vale de Figueira (Santos 2017), led us to plan a campaign of excavations at Penascosa, consisting of the opening of several test pits at key points of the site (Fig. 5).

The fact that at Cardina/Salto do Boi the alluvial accretion at $20 \mathrm{~m}$ a.r.b. stopped by 26000-28000 cal BP (top of layer 5), and that at Penascosa's upriver sector a tenuous 


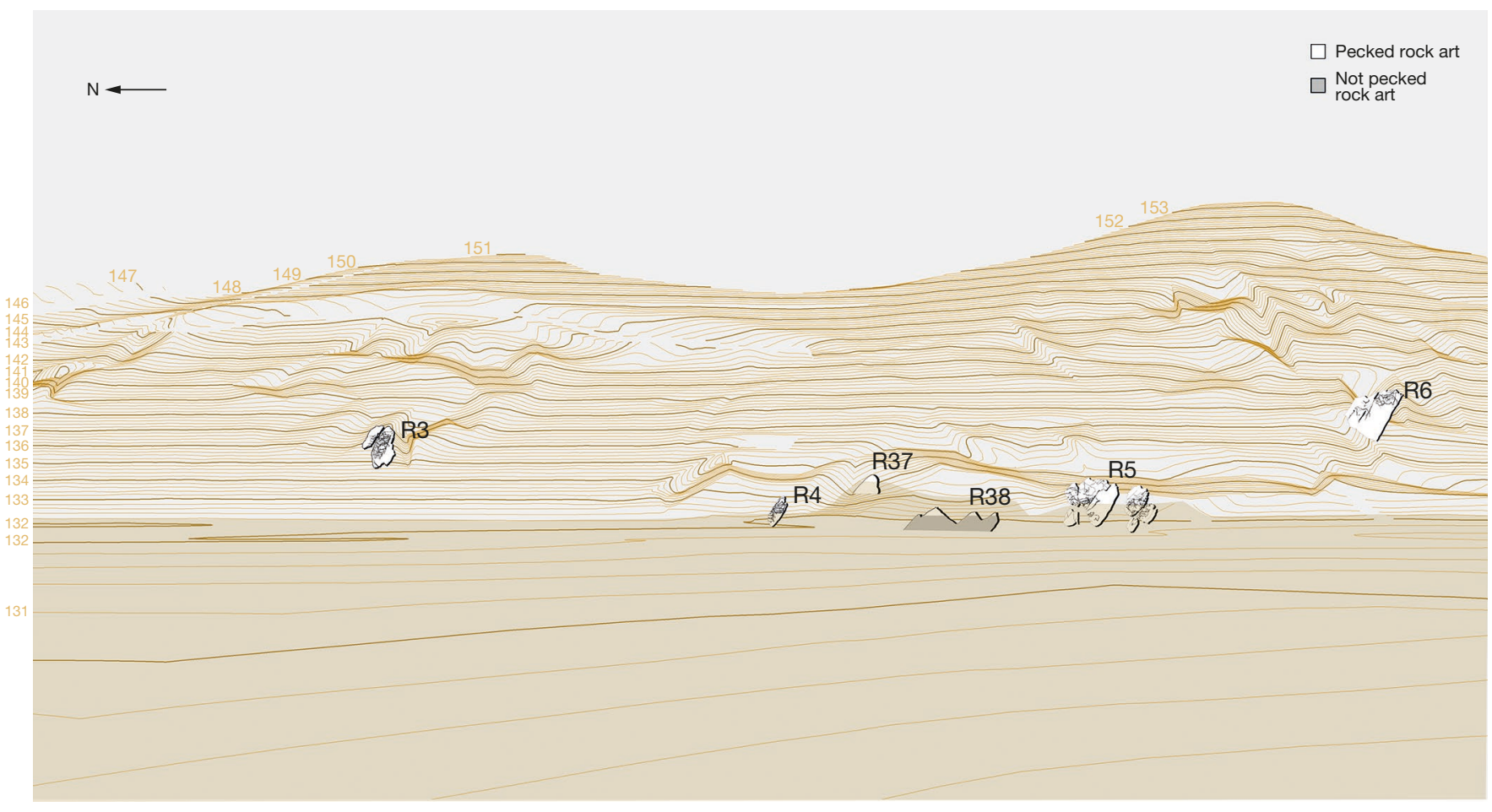

FIG. 6. - Topographic position of the rock art panels 3-6 and newly discovered 37 and 38 panels in the upper sector of Penascosa site.

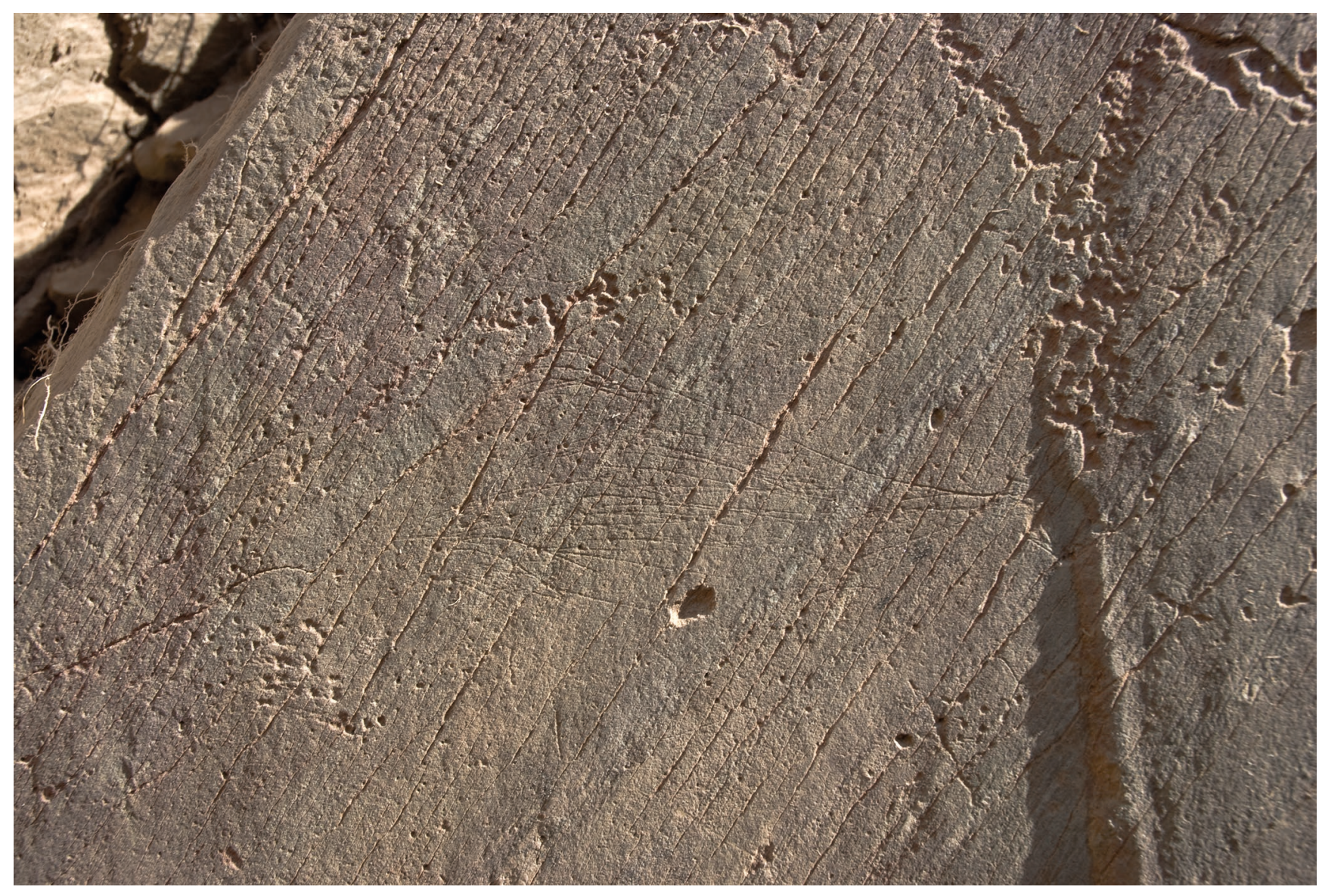

FIG. 7. - Figure assigned to the Azilian, produced by incision of the rock art panel 37 at Penascosa. 


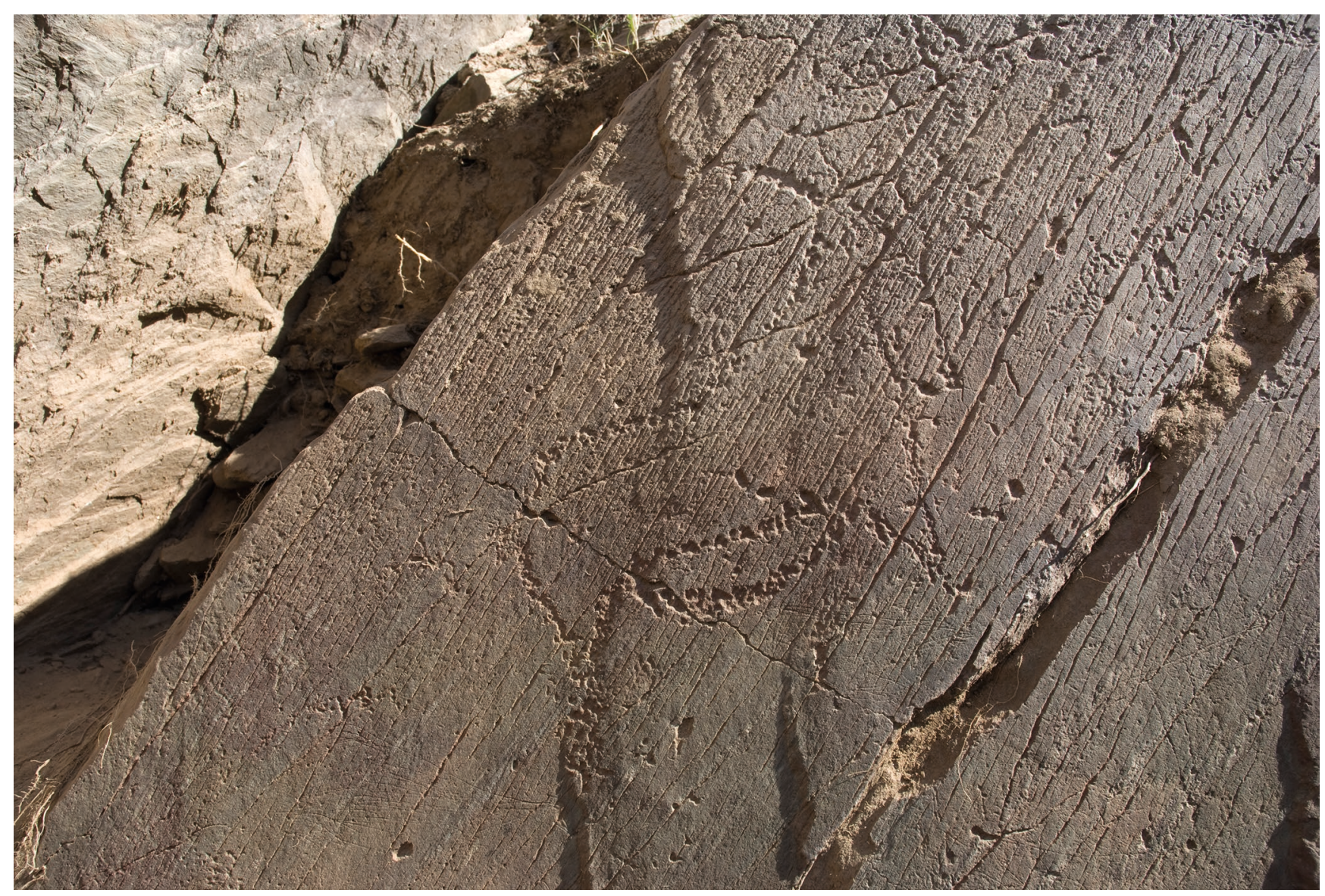

FIG. 8. - Pecked figure assigned to the Magdalenian of the Rock art panel 37 at Penascosa.

but nevertheless significant stylistic difference was found between the engraved rocks located a little higher in the slope (rocks 1, 3, 6 and 8) and those located below (rocks 4 and 5) (Santos 2017) (Fig. 6), led us to test the hypothesis that, until 26000-28 $000 \mathrm{cal} \mathrm{BP}$, the bottom of the alluvial valley was placed at the level of the base of the higher rocks and that an erosional event exposed other panels located at a lower altitude, making it possible to engrave them. This could be related to the local changes identified at Cardina/Salto do Boi. In order to confirm this hypothesis we needed to identify Gravettian layers exclusively at the level of the base of the panels located on higher ground, and/or identify engraved panels of later phases at the level, or below, of Rocks 4 and 5, for which a somewhat later date, relative to the remaining ones discussed in this text, had already been suggested (Santos 2017).

This was not the first attempt to establish a relationship between the engraved panels and other traces of human presence on the site. In fact, several test pits were opened in August 1995, under the direction of J. Zilhão. Two of these test pits were located near Rocks 4 and 5 (Fig. 5), showing that alluvial sands had been deposited there during the Holocene (Zilhão 1997). A trench excavated by mechanical means was also open $300 \mathrm{~m}$ downstream from the engraved rocks discussed in this text (Meireles 1997).
The discovery of metallic objects and modern pottery within the first meter of these deposits, as well as a radiocarbon date (Table 1), prove that the engraved rocks located at the base of the slope were affected by several phases of modern alluvial accretion, namely the most recent, which is related to the construction of a dyke that was used to feed a water mill at the site. These processes are still active today, and the engraved rocks are regularly covered by alluvial sediments during the most intense winter floods, caused by the construction of a cofferdam in the early 1990's (Luís 2018).

The alluvial deposits observed in the trench were of Holocene age, accumulated during several phases of the evolution of the morphology of the main riverbed and of secondary channels, taking the shape of lateral bars with a crisscrossed stratification (Meireles 1997). This process started at least 6000 to 4000 years ago, as shown by the discovery of some Neolithic remains and an OSL age obtained at the bottom of the sedimentary filling (Zilhão 1997).

In the face of these previous works, it was expected that some archaeological evidence could only be recovered on the test pit opened at the level of the higher engraved rocks (Fig. 5), but only slope deposits with no archaeological evidence were found. Conversely, no traces of alluvial deposits, potentially coeval of layer 5 of Cardina/Salto do Boi, were identified. 


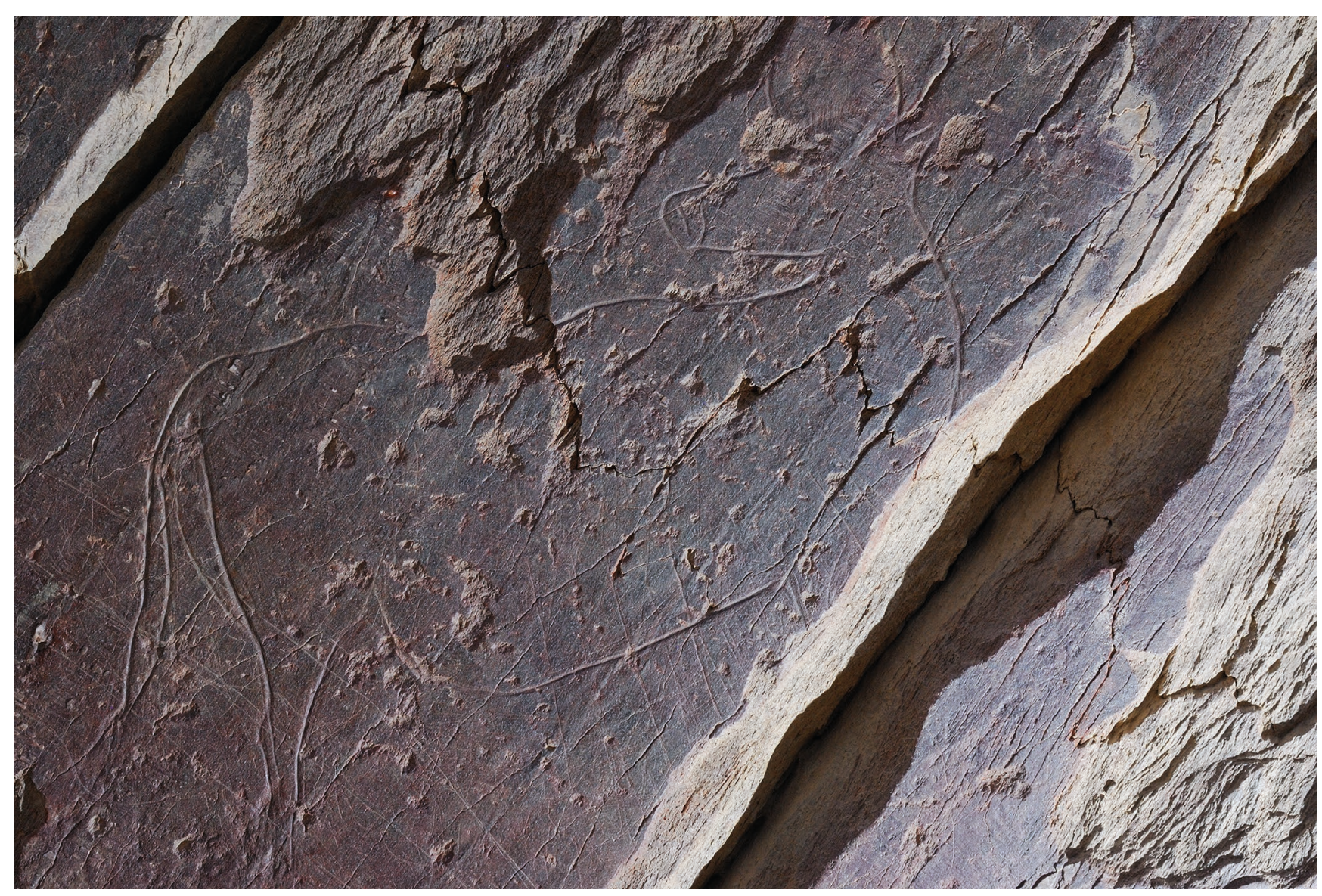

FIG. 9. - Figure assigned to the Magdalenian of the rock art panel 38 at Penascosa

On the other hand, the excavation of the area between Rocks 4 and 5 (Fig. 5), located at the boundary of the current alluvial plain (132.5 $\mathrm{m}$ a.s.l.), provided very important evidence to understand the relationship between engraving and fluvial erosion/accretion. In fact, between these engraved rocks, at a higher altitude, a new engraved rock was found (Rock 37). In this panel, several incised figures could be assigned to the Azilian, comprising a pecked ibex, very similar to VC06-03 (Santos 2017: vol. II, 291), and two striated animals, one of them a red deer doe (Fig. 7), with strong similarities to the figures of the portable art of Fariseu (Santos et al. 2018). The clearest motif is a pecked male ibex (Fig. 8) with strong technical and morphological resemblance to RV01-02 (Santos 2017: vol. II, 265) and morphological resemblance to VC05-01 (Santos 2017: vol. II, 290), both of which have been assigned to the Magdalenian.

Below rock 37 (Fig. 6), a second engraved rock was found during the excavation (Rock 38), where only stylistically Magdalenian motifs were found. In the main panel, several aurochs (Fig. 9), a couple of horses, at least one red deer stag and several signs were identified. In a second panel, a red deer doe was also found. The main reference to this panel is Piscos' Rock 24 (Santos 2017: vol. II, 121-168). Technically, most of the figures were engraved through simple and repeated incision, but abrasion is also present, namely in the case of the red deer doe, which was previously pecked. Some pecked traces are scattered through different panels of the rock, testifying to the non-integrity of the decorated surfaces. These pecked trace remains are only found in the upper parts of the preserved surfaces and in the main panel and are superimposed by the incised and abraded figures, suggesting that the top part of rock 38 had already been engraved before the Magdalenian.

Rock 38 was exclusively covered by Holocenic alluvial deposits, while in front of Rock 37, under these deposits, a slope deposit was discovered behind several fallen blocs (Figs 5; 10). Lithic remains were found inside this deposit, but they do not allow any clear dating. However, the use of fine-grained filonian quartz and comparison with the raw material attested in the regional sites suggest an Upper Pleistocene attribution (Aubry 2009a), which could be related to the engraving of Rock 37.

The finding of engraved rocks with motifs stylistically dated from phase 2 onwards reinforces the idea that Rocks 4 and 5 are truly later than the other remaining pecked and abraded rocks of the site, as previously suggested (Santos 2017). The altimetric difference between the cluster formed by these Rocks (4, 5, 37 and 38) and the base of the panels of the site with phase 1 rock art (Fig. 6) strongly suggests that the former were not visible when the latter were engraved. 


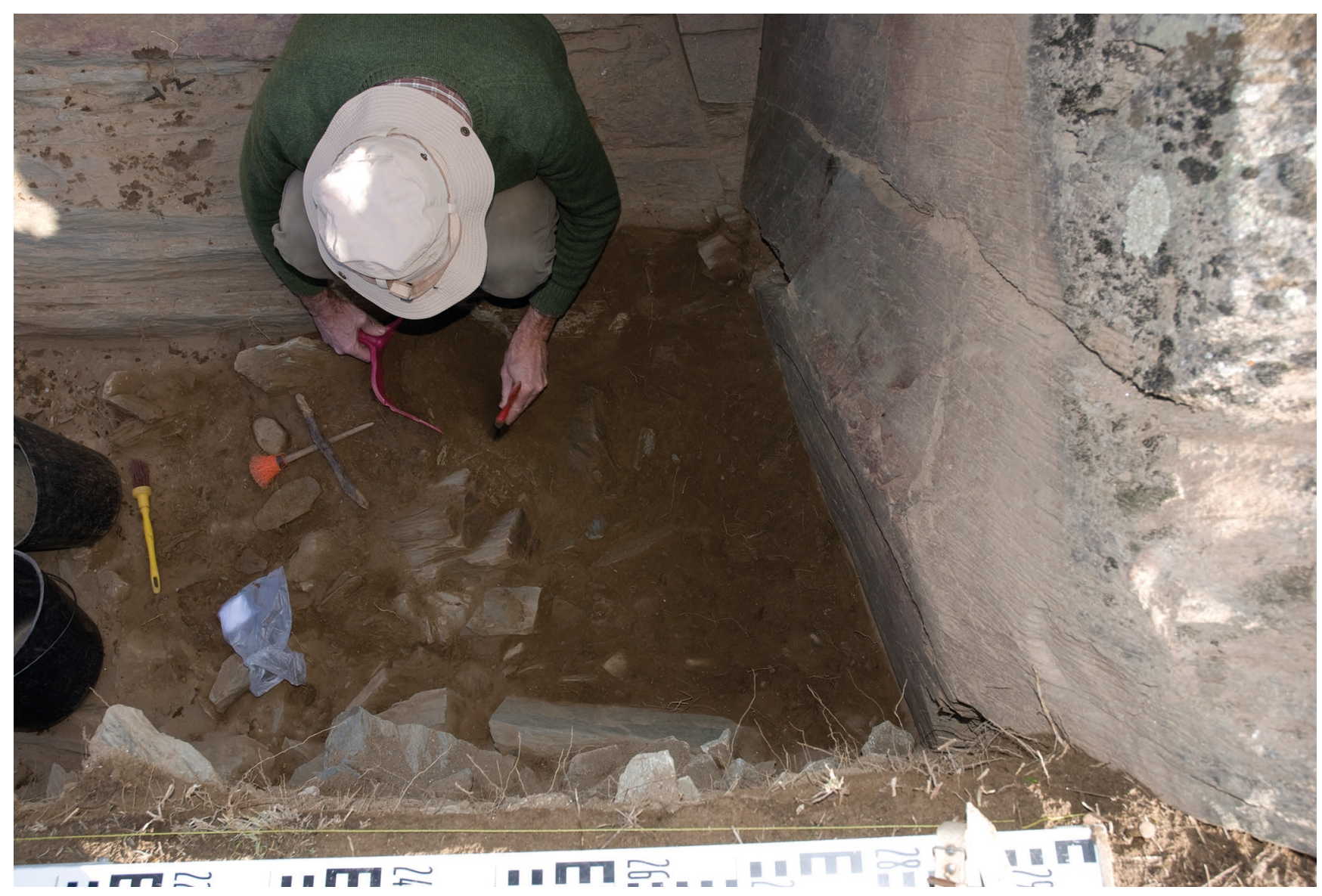

FIG. 10. - Excavation of the geological field unit 4 in front of the rock art panel 37.

They were only exposed after an erosive phase that took place after the engraving of the rocks located higher on the slope.

\section{FoZ DE Piscos: FluVIAL SYSTEM AND DIFFERENTIAL PRESERVATION POTENTIAL}

The rock art of Ribeira de Piscos is scattered around the mouth of the eponymous stream, located three km downriver from Penascosa, in the Côa left bank. It is dated from different phases of the Upper Palaeolithic and later periods (Baptista 1999; Santos 2017).

In a test pit opened in front of Rock 24 (131 m a.s.l. and $10 \mathrm{~m}$ a.r.b), a sequence of four slope deposits was observed and two archaeological layers (GFU 2 and 3) were identified with several lithic remains difficult to date, but with no pottery (Luís 2009; Table 1). These two layers covered incised figures stylistically attributed to the Magdalenian, most probably from its early phase (Santos 2017). Luminescence measurements of two samples from layer 3 are currently in progress at the Center for Nuclear Technologies, Technical University of Denmark, DTU Risø Campus.

Other test pits were opened in 1999, by G. Zambujo, on the base of the slope of a meander located on the opposite margin of the river Côa (Fig. 11). Although several lithic remains were found, they do not allow a cultural attribution. We returned to the site in 2019 and opened eight other test pits of $1 \times 2 \mathrm{~m}$, in order to determine the sedimentary sequence and try to better characterize the lithic remains found in 1999 .

The sedimentary sequence $(130 \mathrm{~m}$ a.s.l. and $9 \mathrm{~m}$ a.r.b. before the construction of the Pocinho dam) found under the silts deposited after the construction of the cofferdams of the Foz Côa dam project is characterized by an alternation between colluvium and alluvium (Fig. 11; Table 1). The discovery of a handmade potsherd in layer 3 of test pit 6 (Fig. 6) is an indication that the lithic remains (essentially milky quartz), although not diagnostic, are probably related to the remobilization of the human occupation remains that were originally located higher on the slope and were later integrated into the alluvial deposits on the base of the slope, during Late Prehistory.

The oldest slope deposit was identified in bedrock depressions in test pits 1, 2, 13 and 14 (Fig. 11[GFU 4]; Table 1). No archaeological remains were found. All the joint/fractures found in the excavation are less than $50 \mathrm{~cm}$ high and have an orientation parallel to the river.

Unlike the excavation at Fariseu, located one km downstream on the opposite bank of the Côa, at the same relative elevation, Foz dos Piscos' excavation did not reveal alluvial Pleistocene deposits or an archaeological context related to the Palaeolithic rock art. This contrast confirms 

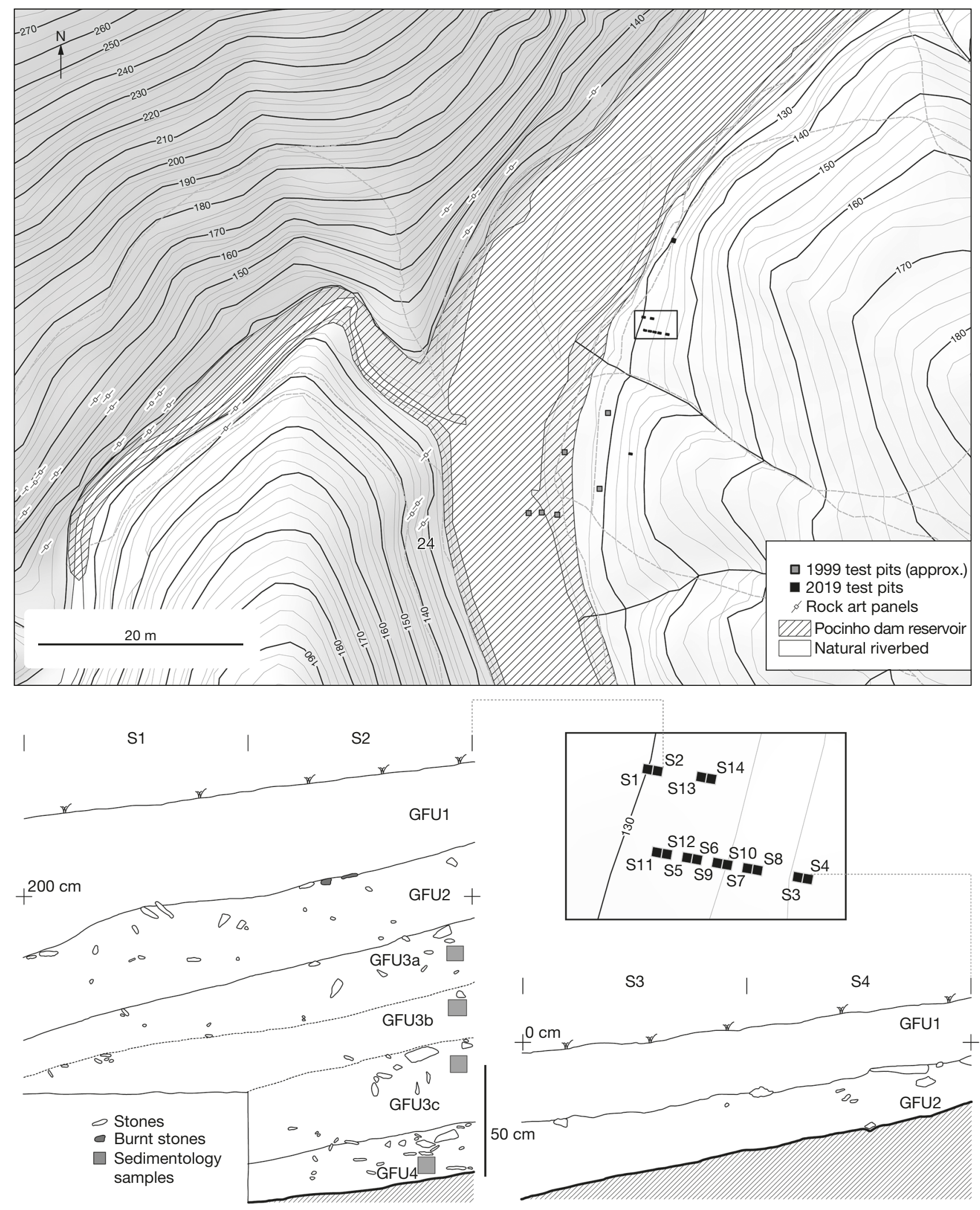

FIG. 11. - Foz de Piscos, location of the 1999, 2019 and panel 24 test pits. Cross-sections of S1/S2 and S3/S4 test pits.

that the conservation of Pleistocene sedimentary packages is highly conditioned by local geomorphology and by the presence and orientation of joint/fractures in the bedrock.
The study of the joint/fractures of the region has showed that they follow a general SW-NE orientation, depending on the axis of the Hercynian tensions, and because of 

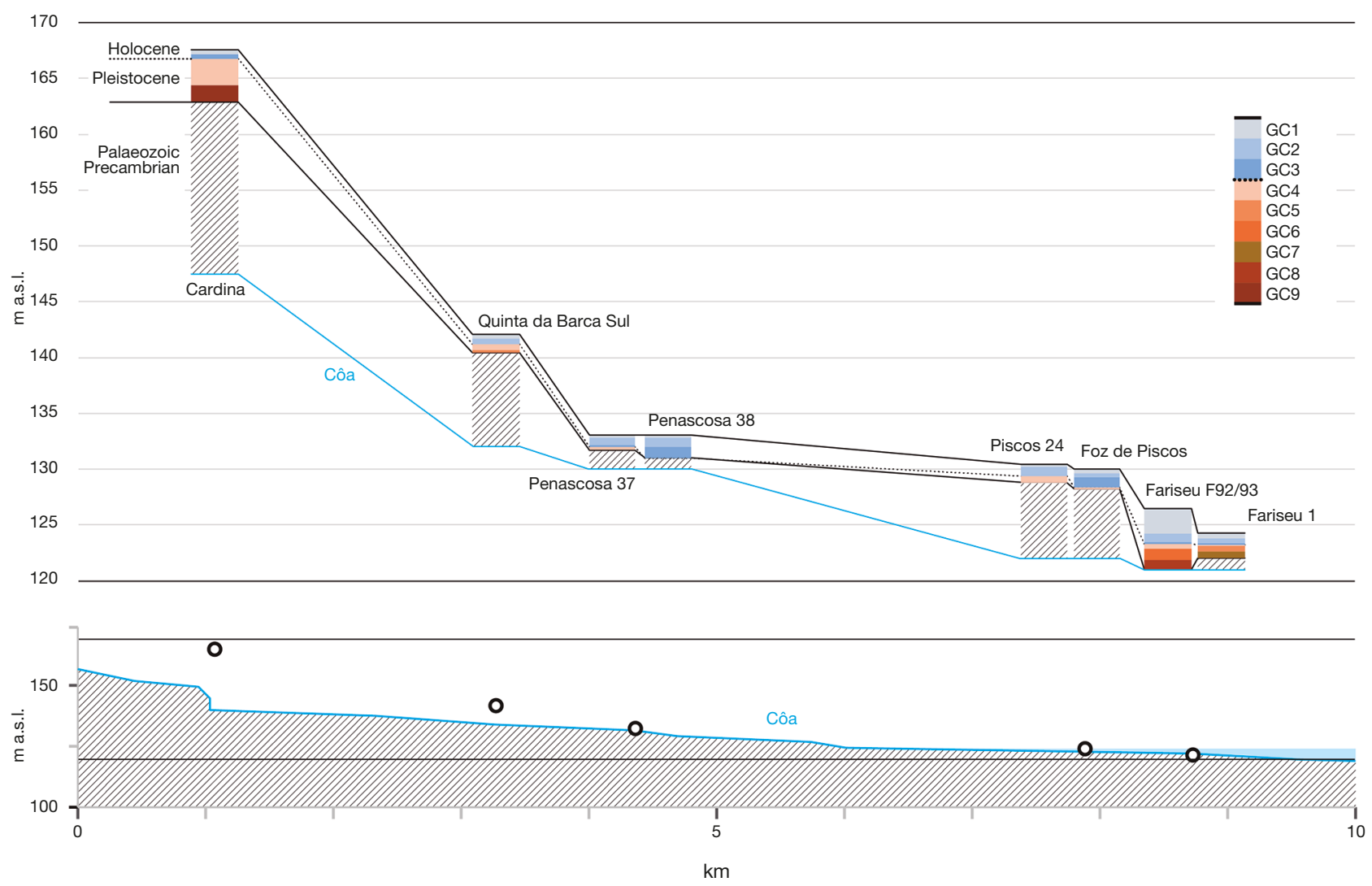

FIG. 12. - Côa Valley Quaternary stratigraphical correlation (see Table 1) and position on the longitudinal profile between Cardina/Salto do Boi and Fariseu.

it panels on the left bank, exposed to the SE, have better conditions for preservation, because they present a higher exposition to solar radiation, limiting humidity and lichendriven weathering (Aubry et al. 2012). Joint/fractures on the left bank are therefore more likely to fix and protect the sedimentary packages from fluvial erosion, as shown by the excavations near Rocks 24 of Piscos (Luís 2009) and 1 of Fariseu (Aubry \& Sampaio 2009). It is probably worthwhile to remember that the best-preserved sedimentary sequence identified in the bottom of the valley is located at Fariseu (125.5 m. a.s.1, $4.5 \mathrm{~m}$ a.r.b.) on the left margin, where the orientation of the joint/fractures form an almost right angle with the riverbed, in the context of a meander that limits runoff erosion.

\section{CONCLUSIONS}

GEOMORPHOLOGIC EVOLUTION OF THE FLUVIAL SYSTEM OF THE LOWER CÔA VALLEY

The textural and structural description and the architecture of the studied sedimentary sequence, as well as the interpretation of the colluvial and alluvial processes and of their depositional environments, allows us to establish a stratigraphic correlation between different geomorphologic units of the lower Côa Valley (Table 1; Fig. 12). We are therefore able to complete the correlational frame of the litho-stratigraphic units of the Côa Valley previously proposed (Aubry et al. 2010, 2011).
Our data confirm the hypothesis that was put forward based on observations of the upper ensemble of Cardina/Salto do Boi, that Late Gravettian and Azilian occupation layers are better preserved (Bergadà 2009; Zilhão et al. 1995) and that the sequence presents several sedimentation hiatuses, as well as different phases of generalized slope destabilization, due to climatic changes and/or to Holocene land use (Zilhão 1997).

Our observations complete this scheme by providing data related to the evolution of the fluvial system. They reveal the existence of different alluvial accretion in a low energy depositional environment through the Middle Palaeolithic and Early Upper Palaeolithic, before $26 \mathrm{ka}$. These conditions favour the conservation of the spatial organization of the archaeological remains of both Neanderthals and first anatomically modern humans in the site of Cardina/ Salto do Boi.

At this same site an important change in the fluvial system related to the lowering of the riverbed was identified. This change occurred after the Gravettian occupation with Noailles burins, and before the Middle Solutrean, identified by laurel leaf fragments found at the base of the slope deposit of layer 4 (Table 1). The effects over the erosional fluvial processes that this change must have originated could be the cause of the fluvial erosional event that washed away the coeval soil of the carving of phase 1 engravings in Penascosa/Quinta da Barca, Fariseu, Vale de Figueira and Canada do Inferno's upriver sector, and exposed new surfaces that were engraved from phase 2 onward in those same sites. 


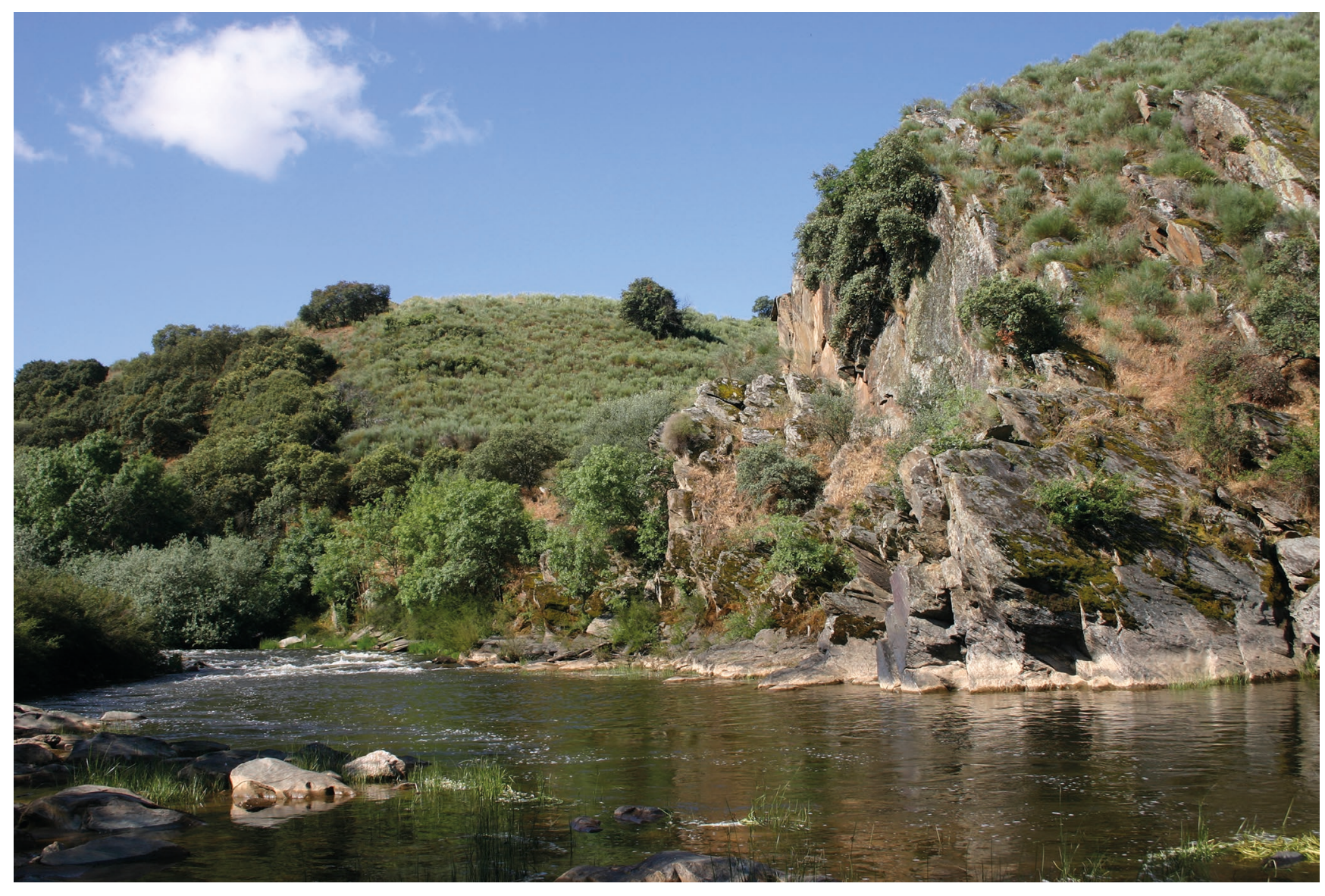

FIG. 13. - Quinta da Barca rock art panel 9.

The dates obtained from Quinta da Barca Sul's GFU 4 , Fariseu's GFU 6, and other alluvial sequences downstream along the Douro Valley confirm the existence of a phase of generalized alluvial accretion during the Greenland Interstadial 1 (Rasmussen et al. 2014), that was partially eroded before the deposition of the Greenland 1 (Late Dryas) slope deposits (Table 1).

The excavation at Foz de Piscos, on a meander at less than one kilometre from Fariseu but on the opposite bank, confirmed that both the topography of the bedrock and the orientation of the joint/fractures, relative to the orientation of the watercourse, are highly conditioning factors for the meandering evolution and correlative preservation of the Pleistocene sedimentary record.

\section{ACCESS TO THE ROCK PANELS AND VISIBILITY OF THE} ENGRAVED PANELS OVER TIME

The data previously presented allows us to establish relationships between geomorphologic and palaeoenvironmental evolution, chronology of rock art production, and topographic location of the rocks that were engraved at the boundary between the alluvial plain and the rocky slopes.

The oldest phase of rock art production, dated from between the Gravettian and the Early Solutrean, appears higher on the slopes than rock art stylistically assigned to later phases at the site of Penascosa and at Canada do Inferno's upriver sector. The chronological frame of the sedimentary processes and the correlated river system evolution can explain this. In fact, this topographic difference can be related to a change in alluvial deposition processes during the Late Gravettian (26-28 ka) that was identified at Cardina/Salto do Boi (Table 1). The lowering of the Côa riverbed must have increased erosional processes downriver, namely over the alluvial package of Penascosa/Quinta da Barca, located three kilometres downriver (Figs 1; 4). The present data allows us to hypothesize that a reconstructed topography taking as reference altitudes the bases of panels 3 and 6 of Penascosa, 16, 17 and upper sectors of Rocks 10 and 11 of Canada do Inferno (both with later motifs located quite apart and in lower areas of the same panels where phase 1 motifs are also present), the upper sector of Rock 1 of Vale de Figueira, and the alluvial deposits of the bottom of the central test pit of Fariseu (GFU 9 and 10) should be chronologically equivalent with the top of GFU 5 of Cardina/Salto do Boi.

However, we find some spots in the valley where the rule "older rock art located near the alluvial plain is always at higher altitudes than the later ones located at the same spots" seems not to be "respected". This happens around the mouth of the stream of Quinta da Barca, at Canada 


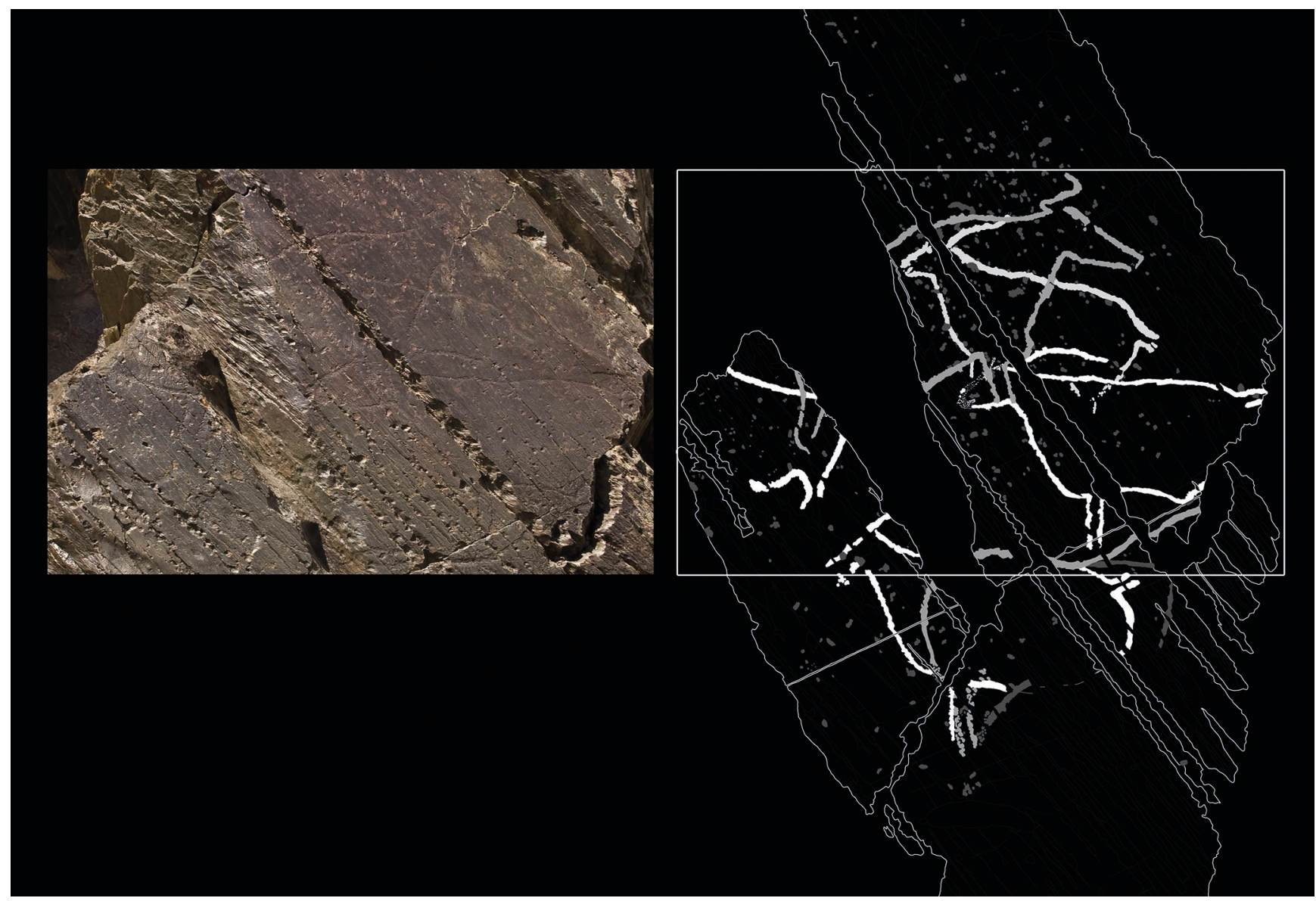

FIG. 14. - Drawing and photograph of the Quinta da Barca panel 9.

do Inferno's downriver sector (Santos 2017) and at Fariseu. This is probably explained by the geomorphology of these places. The first two places were too close to the river course when phase 1 motifs were made. We know this because the rock art from this phase that is at lower altitudes in these spots are systematically affected by fluvial erosion. In the case of Quinta da Barca we observe this in Rock 9 (Figs 13; 14) and at Canada do Inferno in several rocks of the base of what is known as the "Shelter of the ibexes" (Fig. 15). This shelter, located in Canada do Inferno's downriver zone, is much closer to the river than the rocks with phase 1 rock art of Canada do Inferno's upriver sector (Fig. 2). As at Quinta da Barca, the rocks with phase 1 rock art in this spot are also eroded by fluvial action (e.g. Rocks 27 and 31 in Baptista 1999: 78, 79). In other words, the rule that we spoke of above was not even "disrespected" because in these places between the lower engraved rocks and the watercourse, erosion was more important than accretion and, as such, there was no alluvial plain.

At Fariseu, we have already mentioned that the relationship between the orientation of the joint/fractures and the relationship of the stream to preserve the sedimentary filling of the erosional processes (Aubry et al. 2014). For instance, Rock 19 of the site is still covered by GFU 3, which indicates that the early Holocene erosional episode that affect GFU 3 (Table 1) only uncovered part of the existing engraved rocks. Likewise, the Pleistocene erosional episodes must have been restrained at the site by its specific geomorphology and probably their intensity was not enough to expose new panels.

The style of some of the figures of Rock 37 of Penascosa, discovered during the campaign of 2018, proves that the panel was accessible during the Azilian and that the probable alluvial deposits related to the generalized alluvial accretion identified in the region (c. 13-15 ka), namely at Quinta da Barca Sul located several hundred meters upriver, were eroded before the Late Dryas. On the other hand, the topographic position of Rock 38, with motifs attributed to the Magdalenian (Fig. 9), also discovered during the campaign of 2018, shows that this engraved rock, which was entirely covered by modern alluvial deposits, was engraved when the soil was lower than today. Its exposure should have resulted from an erosive phase prior to the generalized fluvial accretion that occurred between 13 and $15 \mathrm{ka}$, during which it was surely covered. This generalized fluvial accretion between the engraving of phase 3 (Middle and Late Magdalenian) and phase 4 rock art (Azilian) should explain why, at most locations near the alluvial plain where both type of engravings are found, the Azilian ones are always located higher than the Magdalenian (besides Penascosa, see also Ribeira 


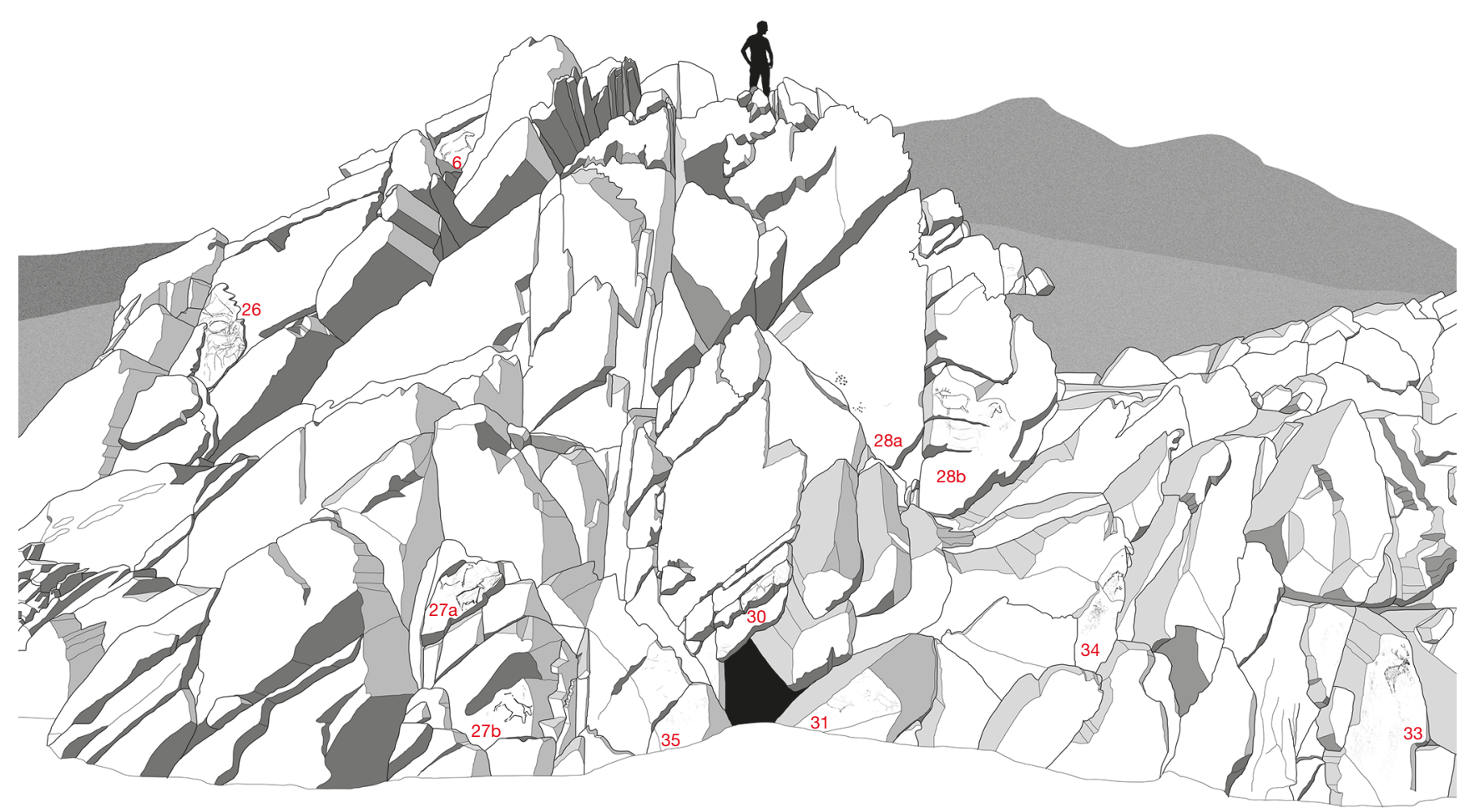

FIG. 15. - Topographic position of the rock art panels $6,26,27,28,30,31,33,34$ and 35 in the Canada do Inferno downriver sector.

de Piscos, Fariseu). However, this difference does not exist between phase 2 (Late Solutrean/ Early Magdalenian) and phase 4, as we saw at Penascosa where Rock 5 is at the same elevation as Rock 37 (see Fig. 6). At Quinta da Barca's downstream sector, Azilian figures are also at the same level, or even at lower locations than phase 2 engravings. This does not necessarily mean that the generalized fluvial accretion that happened between 13 and 15 ka only covered phase 3 rock art and "restored" the Late Solutrean/ Early Magdalenian topography. In fact, the excavation at Fariseu showed that a new erosional episode occurred after this fluvial accretion. At Penascosa, the fluvial accretion could have even reached higher than the base of phase 2 panels, but the ensuing erosion episode could have washed away part of those sediments. At Quinta da Barca's downriver sector, this erosional episode must have been stronger. At Fariseu, which, as we noted previously, is better protected from the fluvial erosional processes, part of those sediments was still covering phase 1 rock art in panel 1, when they were excavated.

These inferences lead us to a very important conclusion: phase 2 and phase 3 engravers saw the images previously done. In general, they respected the older panels, and the additions were made so as not to erase the previous images. In fact, even in the cases where an animal is transformed into another, there is no effort to conceal the original species. Such are the cases in the transformation of a phase 2 horse (Fr04-02) into a phase 3 aurochs (Fr04-01) on Rock 4 at Fariseu, or the adding of a phase 2 horse's head (Pn03-06) to a phase 1 aurochs (Pn03-08) on Rock 3 of Penascosa (Santos 2017). Azilian engravers did not see all the previous engravings, because they were partially buried. In the cases where they saw previous motifs, sometimes they respected them and sometimes they didn't. Examples of the first case can be found on Rocks 41 at Canada do Inferno, 5 and 8 at Fariseu and 4 of Vale de José Esteves, while on Rocks 23 at Quinta da Barca 14, 19 and 22 at Canada do Inferno and 1 at Tudão it is possible to identify examples of the later (Santos 2017).

Our knowledge of the Late Glacial geomorphologic evolution of the valley, its human occupation, and the causes behind the engraving of certain rocks become more and more detailed as we fine-tune the chronology and characterization of the sedimentary record. However, the Quaternary sedimentary filling is unknown at several points and there are discontinuities that need to be better understood. Some of these discontinuities are responsible for our ignorance regarding Solutrean and especially Magdalenian occupations. In fact, although Gravettian and Azilian occupations of the valley are relatively well preserved, Solutrean and Magdalenian occupations are not, due to depositional hiatuses and erosional episodes. Some archaeological pieces and absolute dates confirm, however, the existence of these occupations. At this moment, the Aurignacian has only been identified at Cardina/Salto do Boi. Therefore, it is still poorly known, as well as its potential relationships to the rock art of the region. On the other hand, the phasing of the graphic sequence between the Gravettian and the Azilian is well established, namely by the arguments presented throughout this paper.

The data show that the sedimentary filling and disconformities are highly conditioned by global palaeoenvironmental evolution but also by local geomorphology of the Côa catchment. 
To infer past conditions from sedimentary filling and to study its relationship to human settlement, it is imperative that we increase our knowledge about those processes and relations, particularly those that took place in the area now flooded by the reservoir of Pocinho (Fig. 1), in order to better define the conservation potential of the sedimentary deposits and the related human occupation.

\section{Acknowledgements}

This study is a contribution to the Project PALÆCOA: Neanderthal to Anatomically Modern Human transition in the Côa Valley: Environments, Symbolism and Social networks (PTDC/EPH-ARQ/0326/2014), funded by the Fundação para a Ciência e Tecnologia (FCT) and the Europe 2020 Programme - FEDER (POCI-01-0145-FEDER-016605). The DGPC provided permit for this project. We thank the Fundação Côa Parque for its logistical support and permission to conduct the project on which this study is based.

\section{REFERENCES YACIMIENTO RUPESTRE DE SIEGA VERDE, SALAMANCA}

Alcolea González R. \& Balbín Behrmann J. J. 2006. - Arte paleolitico al aire libre. El yacimiento rupestre de Siega Verde, Salamanca. Junta de Castilla y León, 16.

ANGELUCCI D. 2003. - A partir da terra: a contribuição da geoarqueologia, in Mateus J. E. \& Moreno-GarCia M. (eds), Paleoecologia Humana e Arqueociências. Um programa Multidisciplinar para a Arqueologia sob a Tutela da Cultura. Instituto Português de Arqueologia, Lisboa. Trabalhos de Arqueologia 29: 36-84.

AUBRY T. 2001. - L'occupation de la basse vallée du Côa pendant le Paléolithique supérieur, in ZILHĀO J., AUBRY T. \& CARVALHO A. M. F. de (eds), Les premiers hommes modernes de la Péninsule Ibérique. Actes du Colloque de la Commission VIII de l'UISPP. Instituto Português de Arqueologia, Lisboa. Trabalhos de Arqueologia 17: 253-273.

AUBRY T. 2002. - Le contexte archéologique de l'art paléolithique à l'air libre de la vallée du Côa, in SACCHI D. (ed.), L'art paléolithique à l'air libre. Le paysage modifié par l'image, TautavelCampôme, 7-9 octobre 1999. GAEP, GÉOPRÉ, Tautavel: 25-38.

AUBRY T. 2009a. - Abordagem tipológica dos conjuntos líticos: contribuição para a definição da sequência crono-estratigráfica de ocupação humana do Vale do Côa, in AUBRY T. (ed.), 200 séculos de história do Vale do Côa: Incursóes na vida quotidiana dos caçadores-artistas do Paleolítico. Instituto Português de Arqueologia, Lisboa. Trabalhos de Arqueologia 52: 348-356.

Aubry T. 2009b. - Datação indirecta da arte do Vale do Côa, estratigrafia, arte rupestre e móvel, in AUBRY T. (ed.), 200 séculos de história do Vale do Côa: Incursóes na vida quotidiana dos caçadores-artistas do Paleolítico. Instituto Português de Arqueologia, Lisboa. Trabalhos de Arqueologia 52: 361-373.

AUBRY T. 2009c. - Quadro cronológico e estrutural do entalhe fluvial, in AubRY T. (ed.), 200 séculos de história do Vale do Côa: Incursóes na vida quotidiana dos caçadores-artistas do Paleolítico. Instituto Português de Arqueologia, Lisboa. Trabalhos de Arqueologia 52: 97-102.

Aubry T. 2009d (ed.). - 200 séculos de história do Vale do Côa: Incursóes na vida quotidiana dos caçadores-artistas do Paleolítico. Instituto Português de Arqueologia, Lisboa. Trabalhos de Arqueologia 52: 1-512.

Aubry T. \& GARCÍA DíEZ M. 2000. - Actualité sur la chronologie et l'interprétation de l'art de la vallée du Côa (Portugal). Les Nouvelles de l'Archéologie 82: 52-57.
Aubry T. \& Sampaio J. D. 2008. - Fariseu: new chronological evidence for open-air Palaeolithic art in the Côa valley (Portugal). Antiquity 82 (316): Project Gallery. http://www.antiquity. ac.uk/ProjGall/aubry/index.html

Aubry T. \& Sampaio J. D. 2009. - Escavaçôes e sondagens, in Aubry T. (ed.), 200 séculos de história do Vale do Côa: Incursóes na vida quotidiana dos caçadores-artistas do Paleolítico. Instituto Português de Arqueologia, Lisboa. Trabalhos de Arqueologia 52: 36-83.

Aubry T., Mangado Lliach X., Sampaio J. D. Mangado Llach J. D. \& Sellami F. 2002. - Open-air rock art, territories and modes of exploitation during the upper Palaeolithic in the Côa Valley (Portugal). Antiquity 76: 62-76. https://doi. org/10.1017/S0003598X0008981X

Aubry T., Luís L. \& SAmpaio J. D. 2006. — Primeira datação absoluta para a arte paleolítica ao ar livre: os dados do Fariseu (Vila Nova de Foz Côa). Al-Madan 14: 48-52.

Aubry T., Dimuccio L. A., Bergadà M. M., Sampaio J. D. \& SELLAMI F. 2010. - Palaeolithic engravings and sedimentary environments in the Côa River Valley (Portugal): implications for the detection, interpretation and dating of open-air rock art. Journal of Archaeological Science 37: 3306-3319. https:// doi.org/10.1016/j.jas.2010.07.033

Aubry T., Dimuccio L. A., Almeida M., Neves, M.-J., AngeLUCCI D. E. \& CUNHA L. 2011. - Palaeoenvironmental forcing during the Middle-Upper Palaeolithic transition in centralwestern Portugal. Quaternary Research 75: 66-79. https://doi. org/10.1016/j.yqres.2010.11.002

Aubry T., Luís L. A \& Dimuccio L. A. 2012. - Nature vs. Culture: present-day spatial distribution and preservation of open-air rock art in the Côa and Douro River Valleys (Portugal). Journal of Archaeological Science 39: 848-866. https://doi. org/10.1016/j.jas.2011.10.011

AubrY T., SANTOS A. T. \& Luís L. 2014. — Stratigraphies du panneau 1 de Fariseu: analyse structurelle d'un système graphique paléolithique à l'air libre de la vallée du Côa (Portugal), in PAillet P. (ed.), Les arts de la Préhistoire: micro-analyses, mises en contextes et conservation. Actes du colloque "Microanalyses et datations de l'art préhistorique dans son contexte archéologique», Madapca-Paris, 16-18 novembre 2011. Samra, Les Eyzies. Paleo, numéro spécial: 259-270. http://hdl.handle. net/10400.26/23441

Aubry T., Barbosa A. F., Gameiro C., Luís L., Matias H., SanTOS A. T. \& SilveSTRE M. 2015. - De regresso à Cardina, 13 anos depois: resultados preliminares dos trabalhos arqueológicos de 2014 no Vale do Côa. Revista Portuquesa de Arqueologia 18: 5-26. http://hdl.handle.net/10400.26/23427

Aubry T., Luís L. \& Dimuccio L. A. 2017. — Porque é que a arte do Côa se concentra na margem esquerda? Condicionantes geológicas e ambientais para a formação e conservaçáo dos suportes artísticos do Vale do Côa”. O Arqueólogo Português, Série 5 (4-5): 133-174. http://hdl.handle.net/10400.26/23434

Aubry T., Barbosa A. F., Luís L., Santos A. T. \& Silvestre M. 2018. - Os Neandertais e os primeiros Homens Anatomicamente Modernos no Vale do Côa: Novidades da Cardina. Côavisáo 20: 57-71. http://hdl.handle.net/10451/36579

Aubry T., Barbosa A. F., Gameiro C., Luís L., Santos A. T. \& Silvestre M. 2019. - Cardina I - Salto do Boi: cinco metros de arquivo da ocupação paleolítica no Vale do Côa. Côavisáo 21: 63-74. http://hdl.handle.net/10451/39260

Aubry T., Dimuccio A. F., Barbosa M., Luís L., Santos A. T., Silvestre M., Thomsen K. J., Rades E., Autzen M. \& MurRAY A. S. 2020. — Timing of the Middle-to-Upper Palaeolithic transition in the Iberian inland (Cardina-Salto do Boi, Côa Valley, Portugal). Quaternary Research: 1-21. https://doi. org/10.1017/qua.2020.43

BAHN P. G. 1985. - Ice age drawings on open rock faces in the Pyrenees. Nature 313: 530-531. https://doi.org/10.1038/313530a0 
Balbín Behrmann R., Alcolea GonzÁlez J. J., Santonja Gómez M. \& Pérez Martín R. 1991. — Siega Verde (Salamanca). Yacimiento artístico paleolítico al aire libre, in SANTONJA GOMEZ M. (ed.), Del Paleolítico a la Historia. Museo de Salamanca, Salamanca: 33-48.

Baptista A. M. 1999. - No tempo sem tempo. A arte dos caçadores paleolíticos do Vale do Côa. Com uma perspectiva dos ciclos rupestres pós-glaciares. Parque Arqueológico do Vale do Côa, Vila Nova de Foz Côa, 186 p.

Baptista A. M. 2009. - O paradigma perdido: O Vale do Côa e a arte paleolitica de ar livre em Portugal. Edições Afrontamento, Parque Arqueológico do Vale do Côa, Porto/Vila Nova de Foz Côa, 254 p.

BERGADÀ M. M. 2009. - Análisis micromorfológico de la secuencia sedimentaria de Cardina I (Salto do Boi, Vila Nova de Foz Côa, Portugal), in Aubry T. (ed.), 200 séculos de história do Vale do Côa: Incursóes na vida quotidiana dos caçadores-artistas do Paleolítico. Instituto Português de Arqueologia, Lisboa. Trabalhos de Arqueologia 52: 112-127.

Brown A. G. 1997. - Alluvial Geoarchaeology: Floodplain Archaeology and Environmental Change. Cambridge University Press, Cambridge (Cambridge manuals in archaeology). https://doi. org/10.1017/CBO9780511607820

Collado Giraldo H. 2006. - Arte rupestre en la cuenca del Guadiana: el conjunto de grabados del Molino Manzánez (AlconchelCheles). Beja: EDIA. Memórias d'Odiana-Estudos arqueológicos do Alqueva, $559 \mathrm{p}$.

Cunha P., Martins A., Gomes A., Stokes M., Cabral J., Lopes F. C., Pereira D., Vicente, G., Buylaert J. P., Murray A. S. \& ANTÓN L. 2019. - Mechanisms and age estimates of continental-scale endorheic to exorheic drainage transition: Douro River, western Iberia. Global and Planetary Change 181. https://doi.org/10.1016/j.gloplacha.2019.102985

Jorge S. O., Jorge V. O., De Almeida C. A. F., De J. SanCHES M. \& DE M. T. Soeiro 1981. - Gravuras rupestres de Mazouco (Freixo de Espada à Cinta). Arqueologia 3: 3-12. http://hdl.handle.net/10400.26/25194

Luís L. 2009. — Rocha 24 da Ribeira de Piscos: contexto estratigráfico de uma rocha gravada, in AUBRY T. (ed.), 200 séculos de história do Vale do Côa: Incursóes na vida quotidiana dos caçadores-artistas do Paleolítico. Instituto Português de Arqueologia, Lisboa. Trabalhos de Arqueologia 52: 84-93.

LUís L. 2018. - As gravuras ainda não aprenderam a nadar: impacto das cheias na arte rupestre do Vale do Côa entre 1996 e 2016. Al-Madan Online 22 (1): 10-27.

MarTínez García J. 1986-1987. — Un grabado paleolítico al aire libre en Piedras Blancas (Escullar, Almería). Ars Praehistorica V-VI: 49-58.

MeIreles J. 1997. — O Quaternário do Vale do Côa, in ZILHĀO J. (ed.), Arte rupestre e Pré-história do Vale do Côa. Ministério da Cultura, Lisboa: 41-53.

Mercier N. H. Valladas H., Aubry T., Zilhão,J., Joron J.-L. REYSS J.-L. \& SEllami F. 2006. - Fariseu: first confirmed open-air Palaeolithic parietal art site in the Côa Valley (Portugal). Antiquity 80 (310): Project Gallery.

Mercier N., Valladas H., Froget L., Joron J.-L., Reyss J.-L. \& Aubry T. 2001. - Application de la méthode de la thermoluminescence à la datation des occupations paléolithiques de la Vallée du Côa, in Zilhão J., Aubry T., Carvalho A. M. F. D. (eds), Les premiers hommes modernes de la Péninsule Ibérique. Actes du Colloque de la Commission VIII de l'UISPP. Instituto Português de Arqueologia, Lisboa. Trabalhos de Arqueologia 17: 275-280.

MiALL A. D. 1983. - Basin analysis of fluvial sediments, in CoLLINSON J. D. \& LEWIN J. (eds), Modern and Ancient Fluvial Systems. Blackell Scientific Publishing, London, Special publication of the International Association of Sedimentologists 6: 279-286.
Rasmussen O., Bigler M. , Blockley S. P., Blunier T., BuchaRDt S. L., Clausena H. B., Cvijanovic I., Dahl-Jensena D., Sigfus D., Johnsena J., Fischer H., GKinis V., Guillevic M., Hoek W. Z., Low J. J., Pedro J. B., Popp T., Seierstad I. K., StefFensen J. P., SVensson A. M., Vallelonga P., Vinther B. M., Walker M. J., Wheatley J. J. \& Winstrup M. 2014. — A stratigraphic framework for abrupt climatic changes during the Last Glacial period based on three synchronized Greenland ice-core records: refining and extending the INTIMATE event stratigraphy. Quaternary Science Reviews 106 (201): 14-28. https:// doi.org/10.1016/j.quascirev.2014.09.007

REBANDA N. 1995. - Os trabalhos arqueológicos e o complexo de arte rupestre do Côa. IPPAR, Lisboa, $17 \mathrm{p}$.

REIS M. 2014. - Mil rochas e tal...!: Inventário dos sítios da arte rupestre do Vale do Côa (conclusáo). Portvgalia 35: 17-59.

Rippol López S. \& Municio González L. J. 1992. — Las representaciones de estilo paleolítico en el conjunto de Domingo García (Segovia). Espacio, Tiempo y Forma, Serie I, Prehistoria y Arqueologia, Serie I, 5: 107-138. https://doi.org/10.5944/ etfi.5.1992.4562

RipPol LÓpez S. \& Municio GonZÁlez L. J. 1999. — Domingo García: arte rupestre paleolítico al aire libre en la Meseta. Junta de Castilla y León, Valladolid, Arqueología en Castilla y León 8, 280 p.

Rockwell J., Fonseca J., Madden C., Dawson T., Owen L. A., Vilanova S. \& Figueiredo P. 2009. - Palaeoseismology of the Vilarica Segment of the Manteigas-Braganca Fault in northeastern Portugal, in Reicherter, K, Michetti A. M. \& Silva P. G. (eds), Palaeoseismology: Historical and Prehistorical Records of Earthquake Ground Effects for Seismic Hazard Assessment. The Geological Society, London, Special Publications 316: 237-258. https://doi.org/10.1144/SP316.0

Sacchi J., Abelanet J., Brulé J. L., Massiac Y., Rubiella C. \& VileTte P. 1988. - Le rocher gravé de Fornols-Haut, PyrénéesOrientales. L'Anthropologie 92 (1): 67-100.

SAnTOS A. T. 2017. - A arte paleolítica ao ar livre da bacia do Douro à margem direita do Tejo: uma visáo de conjunto. $\mathrm{PhD}$ Thesis, Faculdade de Letras da Universidade do Porto, Porto, 513 p. https://repositorio-aberto.up.pt/handle/10216/109327

Santos A. T. Barbosa A. F., Aubry T., García Díez, M. \& Sampaio J. D. 2018. - Arte móvel do Fariseu (Muxagata, Vila Nova de Foz Côa). Portvgalia 39: 5-96. https://doi.org/10.21747/09714290/ port39a1

SAnTOS A. T., Luís L. \& Audry T. 2019. - Arte da Sombra: a rocha 7 da Faia (Figueira de Castelo Rodrigo, Guarda, Portugal), um exemplo de arte paleolítica sob abrigo no Vale do Côa. Conimbriga 58: 5-45. https://doi.org/10.14195/1647-8657_58_1

Santos A. T., De J. Sanches M. \& Teixeira J. C. 2015. - The Upper Palaeolithic rock art of Portugal in its Iberian context, in Bueno Ramirez P. \& Bahn P. G. (eds), Prehistoric Art as Prehistoric Culture. Archaeopress Archaeology, Oxford: 123-133.

Sellami F. 2009. - Les données de la séquence stratigraphique du site de Fariseu: processus de déposition et d'érosion des dépôts en limite de la plaine alluviale de la Vallée du Côa, in AUBRY T. (ed.), 200 séculos de história do Vale do Côa: Incursóes na vida quotidiana dos caçadores-artistas do Paleolítico. Instituto Português de Arqueologia, Lisboa. Trabalhos de Arqueologia 52: 103-108.

Valladas H., Mercier N., Froget J.-L., Joron J.-L., Reyss J.-L. \& AUBRY T. 2001. - TL dating of Upper Palaeolithic sites in the Coa Valley (Portugal). Quaternary Science Reviews 20 (5-9): 939943. https://doi.org/10.1016/S0277-3791(00)00026-3

VÁzQUez C. \& ReIS M. 2009. - Arroyo de las Almas (La Fregeneda, Salamanca): un nuevo sitio con arte paleolitico al aire libre. Trabajos de Prehistoria 76 (1): 138-146. https://doi.org/10.3989/ tp.2019.12230

ZILHÃO J. 1995. - The age of the Côa valley (Portugal) rock art: validation of archaeological dating to the Palaeolithic and refutation of "scientific" dating to historic or proto-historic times? Antiquity 69 (266): 883-901. https://doi.org/10.1017/S0003598X00082442 
ZiLHĀo J. 1997. (coord.) — Arte rupestre e Pré-história do Vale do Côa. Trabalhos de 1995-1996. Ministério da Cultura, Lisboa, 453 p. http://hdl.handle.net/10400.26/23253

ZILHÃO J. 2003. - Vers une chronologie plus fine de l'art paléolithique de la Côa: quelques hypothèses de travail, in BALBIN R. \& Bueno Ramirez P. (eds), Primer symposium internacional de arte prehistórico de Ribadesella. El Arte prehistórico desde los inicios del siglo XXI. Asociación Cultural Amigos de Ribadesella, Ribadesella: 75-90.

Zilhão J. T., Aubry T., De Carvalho A. M. F., Zambujo G. \& Almeida F. 1995. - O sítio arqueológico paleolítico do Salto do Boi (Cardina, Santa Comba, Vila Nova de Foz Côa). Trabalhos de Antropologia e Etnologia 35 (4): 471-485. http://hdl.handle. net/10400.26/23482

Submitted on 21 September 2019; accepted on 29 November 2019; published on 2 November 2020. 